IZA DP No. 7331

Male Wage Inequality and Marital Dissolution:

Is There a Link?

Andriana Bellou

April 2013 


\title{
Male Wage Inequality and Marital Dissolution: Is There a Link?
}

\author{
Andriana Bellou \\ Université de Montréal, \\ CIREQ, CIRANO and IZA
}

\section{Discussion Paper No. 7331 \\ April 2013}

IZA

\author{
P.O. Box 7240 \\ 53072 Bonn \\ Germany
}

Phone: +49-228-3894-0

Fax: +49-228-3894-180

E-mail: iza@iza.org

Any opinions expressed here are those of the author(s) and not those of IZA. Research published in this series may include views on policy, but the institute itself takes no institutional policy positions. The IZA research network is committed to the IZA Guiding Principles of Research Integrity.

The Institute for the Study of Labor (IZA) in Bonn is a local and virtual international research center and a place of communication between science, politics and business. IZA is an independent nonprofit organization supported by Deutsche Post Foundation. The center is associated with the University of Bonn and offers a stimulating research environment through its international network, workshops and conferences, data service, project support, research visits and doctoral program. IZA engages in (i) original and internationally competitive research in all fields of labor economics, (ii) development of policy concepts, and (iii) dissemination of research results and concepts to the interested public.

IZA Discussion Papers often represent preliminary work and are circulated to encourage discussion. Citation of such a paper should account for its provisional character. A revised version may be available directly from the author. 


\title{
ABSTRACT \\ Male Wage Inequality and Marital Dissolution: Is There a Link?*
}

\begin{abstract}
After almost a century-long pattern of rising marital instability, divorce rates leveled off in 1980 and have been declining ever since. The timing of deceleration and decline in the rates of marital disruption interestingly coincides with a period of substantial growth in wage inequality. This paper establishes a connection between the two phenomena and explores potential explanations for the underlying link. Using individual data on female marital histories in a duration analysis framework combined with regional and temporal variation in the pattern of male wage dispersion, I show that inequality has a significant stabilizing effect on the marital relationship. Quantitatively, increases in male wage dispersion can roughly explain up to $30 \%$ of the fall in the mean separation probability between 1979 and 1990. Several plausible explanations for this relationship are assessed: changes in spousal labor supplies, female wage inequality, income uncertainty, social capital as well as a hypothesis of "on-themarriage" search. The results are most supportive of the search interpretation. No strong quantitative support was found for the remaining mechanisms.
\end{abstract}

JEL Classification: J11, J12, J31

Keywords: divorce, wage inequality

Corresponding author:

Andriana Bellou

Université de Montréal

Département de Sciences Économiques

C.P. 6128 succursale Centre-ville

Montréal, H3C 3J7

Canada

E-mail: andriana.bellou@umontreal.ca

\footnotetext{
* I would like to thank Mark Aguiar, Uta Schönberg, Rachana Bhatt, and seminar participants at the University of Rochester, University College London, Central Bank of Cyprus, University of Montreal, SOLE meetings (2009) and MEA meeting (2010) for their helpful comments and suggestions.
} 


\section{Introduction}

After almost two decades of sharply rising divorce rates in the United States, rates of marital dissolution leveled off in 1980 and have been declining ever since. Divorce rates in 2009 3.4 divorces per 1000 people - were at their lowest level since 1970 (US Census Bureau). Proposed explanations include the presence of compositional factors such as the aging of baby-boomers, that increased the mean duration of intact marriages, increases in the age at first marriage, a slowing down in the rate of remarriages, rising cohabitation and the technology of birth control. These candidates, however, have yet done little to explain the end of more than a century-long pattern of rising marital instability (Stevenson and Wolfers (2007), Goldstein (1999)).

Nevertheless, the timing of deceleration and decline in the rates of marital disruption interestingly coincides with a period of substantial growth in wage inequality. The latter modestly increased in the mid-late 1970s, starkly escalated in the 1980s and slowed down in the mid-1990s (Goldin and Margo (1992), Juhn et al. (1993), Autor et al. (2005)). The goal of this paper is to first establish whether a connection exists between these two phenomena and subsequently analyze potential explanations for the underlying link.

In order to uncover the impact of growing wage inequality on separations, I use individual data on female marital histories along with geographic (state) and temporal variation in the dispersion of male wages in the context of a duration model. Focusing on the incidence of the first marriage only and on a sample of marriages starting as early as in the 1960s, I show that the greater dispersion in male wages has a stabilizing effect on the marital relationship. This finding is robust across a wide array of specifications including alternative definitions 
for male wage inequality, controls for changes in the female wage structure and selection into marriage, changes in the legal environment surrounding divorce, state-specific time trends, as well as an instrumental variables approach, which uses states' industrial mix in 1960 interacted with year fixed effects as an instrument for wage inequality. Quantitatively, the estimates imply that an increase in male wage dispersion by one standard deviation $(0.047)$ is associated with a fall in the mean separation probability in a given year by roughly $7 \%$. In the context of the declining trend in the rates of divorce since the late 1970s, increases in male wage inequality can explain approximately up to $30 \%$ of the fall in the separation probability between 1979 and 1990. These findings are corroborated using an alternative sample drawn from the 1979 cohort of the National Longitudinal Survey of Youth. Further analysis relying on this data shows that the documented effect operates conditional on spousal and couple characteristics such as education, age at marriage and income. Therefore, the estimates suggest that changes in male wage dispersion have been an important, independent predictor of the changes in divorce behavior over the period of study.

After documenting this association in the data, I proceed by discussing several plausible explanations. I consider four potential mechanisms. First, growing inequality and higher returns to skill may impact on the time investment of spouses in market/career activities relative to marriage-specific time. Such imbalances will affect the degree of household specialization and therefore the returns from marriage. Another possibility is that rising inequality may reflect higher income volatility and therefore uncertainty. Since marriage is a form of consumption insurance that couples enter in order to diversify income risks, growing income volatility may affect the benefits and the costs of staying in the partnership. 
Third, in line with existing research (Loughran (2002) and Gould and Paserman (2003)) the results could be consistent with a model of female marital search whereby married women receive marriage offers, which they can either accept or reject and stay in their current marriage. Under the assumption that the wage signals the quality of a male partner, rising wage inequality could be viewed as an increase in the dispersion of potential husband quality. On the one hand, a larger upper tail increases the odds of divorce by increasing the chances of finding a new acceptable match ("divorce-inducing" effect). On the other hand, however, it lowers the divorce hazard by inducing women to search longer for another partner before exiting their current marriage ( "inhibiting" effect). This is because waiting has an option value: rejecting a low quality proposal today implies that there are chances of a better draw tomorrow. In the presence of non-negligible separation costs, the second effect may dominate thus leading to more search during the marriage. This would then translate into a positive relationship between marriage duration and inequality.

Finally, increases in inequality have been linked to declines in participation in social capital activities centered at the community such as volunteering and organizational activity (Alesina and La Ferrara (2000) and Costa and Kahn (2001)). In more socially interactive environments the opportunities of meeting new people increase, options outside of marriage may consequently improve, which could in turn influence the degree of marital stability.

I empirically assess these hypotheses. The analysis suggests that disaccumulation of social capital, changes in spousal labor supply or growing income volatility are not the primary drivers of my findings. The results instead, while they do not constitute a direct test of the search mechanism, they are suggestive of this interpretation. 
The findings of this paper complement the literature on the social impact of higher inequality in the local labor market. While the causes of higher inequality have been studied extensively - skill-biased technological change, fall in the real value of minimum wage, deunionization - the societal consequences of this structural phenomenon have received much less attention. This paper is most closely related to recent research by Loughran (2002) and Gould and Paserman (2003), who demonstrate a link between male wage inequality and female age at first marriage. Both papers conclude that in areas with higher male wage dispersion, women tend to marry later in life and employ a search-theoretic framework to interpret this finding. Nevertheless, neither of the two studies examines the actual quality of the matches formed and evolved under conditions of rising wage dispersion. This work makes a step further towards this direction and shows that, even after controlling for changes in the age at first marriage, inequality has a distinct positive effect on marital stability.

The remainder of the paper is organized as follows. Section 2 presents the data, descriptive evidence and the econometric methodology. Section 3 analyzes the basic results from the duration model and discusses their robustness to alternative specifications and measures of inequality. Section 4 discusses various explanations while Section 5 concludes.

\section{Data and Econometric Specification}

\subsection{Data}

The analysis uses several data sources. First, I study marital histories extracted from the 1980, 1985, 1990 and 1995 repeated cross-sections of the June CPS. In each of the four 
surveys, the respondents were asked about their first and higher order marriages as well as completed fertility. This information is consistently recorded only for female respondents and is retrospective. ${ }^{1}$ Key individual characteristics are observed such as the age of the respondent at each child birth, the age at first (and higher order) marriage as well as at subsequent separation and divorce (if any), educational attainment and the state of residence at the time of the survey. ${ }^{2}$

The analysis explores first marriages only. In line with much previous work using retrospective marital histories (e.g. Sweeney and Phillips (2004)), I restrict the sample to marriages that are relatively more proximate to the interview date, that is marriages that started within 15 years from the interview date and are either still intact or ended in separation. Effectively, this means that the sample from the 1980 (1985, 1990, 1995) survey consists of respondents whose marriages started no earlier than 1965 (1970, 1975, 1980, 1985). This restriction is applied in order to minimize recall bias driven by marriages that ended long before the survey date. Any first marriage that ended in widowhood is excluded.

Moreover, following previous studies on the determinants of marital dissolution based on individual data, I use separation date (if available) rather than divorce date to identify the timing of marital disruption. Separation is likely a more salient and meaningful definition of dissolution, since the elapsed period between separation and official divorce

\footnotetext{
${ }^{1}$ Focusing on the retrospective marital histories of women rather than men is quite typical in the related literature. Martin (2006) excludes males from his analysis and documents that while female retrospective reports from the SIPP closely match the aggregate data, the male reports do not. Men tend to report fewer marital dissolutions than women, particularly at very long (more than 15 years) or very short (less than three years) durations. Hence, it seems that recall bias is an important issue for male respondents, but less so for females. Finally, there is statistical evidence showing that women are more likely to initiate divorce especially in the presence of children. In 1988, $65 \%$ of divorce cases in the U.S. were filed by the wife, $32 \%$ were filed by the husband and 7\% jointly (National Center for Health Statistics (1991)).

${ }^{2}$ The June CPS ceased to collect marital histories after 1995.
} 
depends on legal factors, state-specific laws and can often be quite lengthy (Castro and Bumpass (1987)). ${ }^{3}$ Following Loughran (2002) and Gould and Paserman (2003), I also focus on white women who married for the first time while in their twenties or later. The latter have likely completed their education and are presumably more exposed to wage-earning men. ${ }^{4}$ Finally, it should be highlighted that while these sample restrictions accord with the related literature on the use of retrospective data, they do not necessarily provide a sample of marriages/separations that are nationally representative in a given year.

An important advantage of the June CPS is that it provides a large effective sample of marital histories that span a very broad time period (1965-1995). This allows for a more credible identification of pre-existing trends in divorce and also facilitates the performance of a series of robustness exercises on the main findings. Nevertheless, these benefits come at a cost of three main limitations that are imposed by the sample design of the June CPS. First of all, the state of residence is the finest geographic unit that is consistently available during all survey years considered in the analysis. This implicitly leads me to define the state as the "local" marriage market of the individual, even though the metropolitan area would be an admittedly more appropriate geographic definition. ${ }^{5}$

\footnotetext{
${ }^{3}$ Nevertheless, the results are robust to using divorce as definition of marital dissolution. The terms separation and divorce are used interchangeably and both correspond to the definition provided in the text.

${ }^{4}$ (i) That being said, the baseline estimates remain quantitatively robust and statistically significant when younger women are included in the sample. (ii) The focus on the population of white females is dictated by two reasons. First, low rates of interracial marriages are observed in the data and therefore it would be appropriate to analyze separately the marriage and divorce behavior of whites and African Americans. With this in mind, the analysis is further restricted by the much smaller sample sizes for African Americans in the CPS.

${ }^{5}$ Even in the absence of this problem, the March CPS Supplements, which will be used to calculate measures of wage inequality, provide scarce information on the metropolitan area of residence of the respondent prior to 1986. This would not allow me to calculate inequality measures for marriages that started prior to 1986 , which would significantly limit the effective sample size for the analysis. As increases in inequality were already taking place since the late 1970s, regional changes in wage dispersion and marital disruption prior to 1986 is a source of variation that I would like to explore. Using a large geographical unit (such as
} 
Furthermore, the information on the location of the respondent is only collected at the time of the interview. There is no retrospective information on geographic mobility that would allow tracking the location of the individual while in the marriage. It is, therefore, necessary to assume that the respondent has been residing in the same state as at the interview date from the year the first marriage begun until the year of separation or the current interview year, if still in the first marriage. If married women randomly change states during this time period, then the estimated effect of inequality on separation might be understated. However, if mobility is endogenous, then the direction of the bias is unclear. ${ }^{6}$ Finally, the June CPS does not record any other retrospective information other than the marital and fertility history of the respondent. As a result, important covariates such as educational attainment are only measured at the time of the interview and furthermore, information on the first husband's income or any other of his characteristics (age, education, earnings/work status) during the marriage are not observed.

To address the latter limitation, I supplement the baseline analysis using the June CPS, with an auxiliary analysis that relies on the 1979 National Longitudinal Survey of Youth the "state") could bias my results against finding an effect of inequality on divorce.

${ }^{6}$ Also see Bailey (2009) for a similar assumption. Although endogenous mobility is a possibility, a first pass in the data shows that mobility among ever-married women mostly takes place within the state of residence. In particular, in an omitted analysis that uses ACS data, I find that wage inequality in the state of residence one year prior to the survey year does not significantly predict between-state migration among married women (and currently in their first marriage) even conditional on contemporaneous state wage inequality. The same is true for recently divorced (that is divorced during the year prior to the interview date) or ever divorced women. Between-state migration is defined as being observed in a different state at interview date relative to the state reported the year prior to that date. The average annual migration propensity within the first 5 years of marriage is $4.5 \%$, declines to $2.6 \%$ for women between the 6 th and 10th year of marriage and subsequently drops to $1.7 \%$ for those married for more than 10 years. The share of recently divorced (ever divorced) women who switch states is $4.5 \%$ (2\%). Given these statistics, it appears that the vast majority of movers migrates either between counties or metropolitan areas within the same state. In this sense, using state as opposed to MSA as definition of the local marriage market could serve to minimize bias resulting from the no-moving assumption. I also focus on marriages that started relatively close to the interview date (when geographic information is collected), which may also increase the chances that the current state of residence coincides with the state of residence while married. 
(NLSY79). The NLSY79 is a nationally representative sample of respondents who were 14-22 years old when they were first surveyed in 1979. These individuals were interviewed annually through 1994 and biennially since then. While the primary focus of the survey is labor force behavior, information on the marital histrory of the respondents is also collected. In order to obtain a sample comparable to the CPS, I apply the same sample selection criteria. My sample consists of approximately 7000 marriage-year observations of white women from the main cross-sectional NLSY sample, whose first marriage took place in or after 1979 and until 2010, which is the last available survey year. An important drawback of this data is the significantly smaller sample size compared to the CPS. However, the NLSY consistently provides information on certain characteristics of the spouses during the course of the marriage. Such information includes their education, age, labor supply and earned income. These features of the data are very important for three reasons. First, they allow examining the validity of the main findings relying on CPS data using an alternative data source. Second, the baseline analysis can be performed controlling for partner-specific characteristics, whose omission may confound the main findings. Third, the availability of information on labor supply and wages allows exploring some potential mechanisms that could be driving the baseline results.

A restriction of the analysis using the NLSY sample pertains to the "geographic" definition of the relevant marriage market of the respondent. For confidentiality purposes, information on the current state/county/SMSA of residence is not available in the public module of the NLS. Given this limitation, I assume that the relevant market of the respondent is defined geographically by her region of residence and her metropolitan status 
(whether or not she resides in an MSA). This stands in contrast to the definition applied to the June CPS data, which assumes that the relevant marriage market of the individual is her state of residence. This assumption, however, will be relaxed in subsequent analysis.

The last data source is the cross-sectional March CPS Supplements. Annual information on wages, employment and other demographic characteristics is collected, which I primarily use to calculate wage inequality. The baseline measure of inequality is the standard deviation in log weekly wages for full-time full-year white males 16 to 64 years old. Nominal variables were converted to real values using the 1982 - 1984 CPI obtained from the Bureau of Labor Statistics. Workers with real weekly earnings that were below $\$ 67$ in 1982 (equal to one half the 1982 real minimum wage based on a 40-hour week) were excluded from the analysis. ${ }^{7}$ I use the same dataset to construct other demographic and socio-economic state covariates: the share of total white male and female population employed, average male and female log hourly wages for white workers as well as sex ratios. These variables will be included as covariates in the hazard model linking inequality at each year of marriage to its duration.

For the analysis using the June CPS, all aggregate covariates including wage inequality are calculated at the state level for all years between 1965-1995. Moreover, while wage dispersion is initially calculated on the full state sample of white males, the remaining aggregate controls are constructed for particular subsets of the state population defined on the basis of educational attainment. ${ }^{8}$ I distinguish two broad education groups - at most high school graduates and at least some college. The presumption is that the hazard of divorce of a given woman is most strongly influenced by changes in the socio-economic environment specific to

\footnotetext{
${ }^{7}$ The same data restriction is used in Katz and Murphy (1992) and Juhn, Murphy and Pierce (1993).

${ }^{8}$ The calculation of aggregate covariates by education group is not crucial for any of the reported findings.
} 
her education group. A similar approach, outlined in the subsequent section, is followed for the construction of aggregate controls for the auxilliary analysis using the NLSY sample.

Finally, one deficiency of the March CPS, specific to the period of study spanned by the June CPS sample, is that certain smaller states are grouped together with others (CPS regions) from 1968 to 1976 and therefore cannot be separately identified. As a result, I choose to restrict attention to years where state information on wages and other labor market characteristics can be clearly identified and computed. Appendix Table 1 lists the years for which such state information can be calculated.

\subsubsection{Descriptive Statistics}

Appendix Table 2 provides an overview of the main characteristics of the baseline sample drawn from the June Supplements of the CPS. Once all restrictions are applied, the baseline sample consists of 31573 marriages, with $18.1 \%$ ending in separation. $60 \%$ of women have more than a high school degree, while $65 \%$ of women gave birth to their first child prior to separation or the interview date (censoring point) if still in their first marriage. The mean age at first marriage is 24.7 years. Statistics on the average risk of separation by years of marriage are also provided. The risk of separation is increasing during the first five years of marriage and then gradually declines. The average risk of separation for a couple in a given year is 2.4 percent, which implies 24 separations per 1000 married women.

Appendix Table 2 presents the same descriptive statistics for the NLSY79 data. After restricting attention to valid observations that satisfy the sample selection criteria, I obtain a sample that consists of approximately 1000 individuals, which is significantly smaller compared to the June CPS. This number slightly fluctuates depending on the specification 
estimated and the variables newly introduced. Despite the reduced sample size, the divorce statistics are comparable to the CPS. Rougly $22 \%$ of first marriages end in divorce while the mean divorce probability in a given year of marriage is 2.4 percent. The average female age at first marriage is slightly higher than in the CPS at 25.06 years. This is expected as the NLSY sample comprises of marriages that on average took place in more recent years than in the CPS, while age at first marriage was increasing. Moreover, since the NLSY includes marriages that started in the 1980s or later when divorce rates were stable or declining but still higher in levels than in the 1960s, this data displays a slightly higher percentage of ever-divorced population that the CPS.

Figure 1 depicts the trends in male wage inequality and female separation rates since the 1970s using the June CPS. ${ }^{9}$ In line with previous studies (Stevenson and Wolfers (2007), Goldstein (1999)), divorce rates rose sharply during the 1970s, levelled off abruptly in the early 1980s and have been declining ever since. In fact, increases in the rate of divorce were already beginning to wane in the mid 1970s (Goldstein (1999)). While these trends have been extensively remarked, alternative theories (compositional changes, increase in the age at first marriage, rising cohabitation, decline/deceleration in remarriage rate, evolving legal environment) have contributed little to explaining the plateau in divorce rates after more than a century-long acceleration. Interestingly, however, the deceleration and decline of divorce rates since the mid-late 1970s coincides with the beginning of an era of rapidly

\footnotetext{
${ }^{9}$ The separation rate is the percentage of first marriages ending in separation in a given year (here 1971, $1975,1979,1985,1990)$ which is calculated using the sample of female respondents with the characteristics described above. Note that as the analysis is restricted to relatively "newer" marriages (i.e that took place with 15 years from the interview date), the risk of separation will be slightly higher than average. The trends, however, in the separation rate are qualitatively similar if the sample is extended to include all women. Inequality is calculated in the manner outlined in the text.
} 
growing wage dispersion both between and within groups. While the 1970s was a period with moderate increases in wage inequality, the 1980s and to a lesser extent the 1990s witnessed a substantial widening in the U.S wage structure (Juhn et al. (1993), Autor et al. (2008)).

To study the relationship between these two phenomena, I explore variation in male wage inequality and separation rates within states over time and across states. This identification strategy will importantly eliminate any time-invariant state-specific factors that are likely correlated with inequality and divorce. A visual cue of this source of variation is depicted in Figure 2, where changes between 1980 and 1990 in the percentage of ever divorced women are regressed on changes in male wage dispersion within states over the same time period. This figure essentially previews my main result: the stock of ever divorced women grew on average less (or declined) in states that displayed greater increases in male wage dispersion. The remaining of the paper further explores the robustness of this negative relationship and seeks to uncover potential explanations for the underlying link. ${ }^{10}$

\subsection{Econometric Specification}

To examine how changes in wage inequality relate to changes in the value (duration) of the marriage, I use a discrete time duration model. To do this, the data is converted to a sequence of yearly observations (person-period format). The duration of interest is the number of years the first marriage has lasted. I consider as starting point the year the marriage took place and as end point the smallest between the year of separation and the

\footnotetext{
${ }^{10}$ The stock of ever divorced women is measured by the fraction of ever-married white women 21 to 55 years old who were interviewed in these years and reported that they had separated at any point prior to or at the survey date. The calculations are based on the 1980 and 1990 June CPS cross-sectional surveys. The relationship depicted in this figure is robust to excluding states with big changes in divorce rates during this period such as Alaska, Idaho, Kentucky, Minnesota, New Mexico and Wyoming.
} 
year of formal termination of the first marriage. The censoring indicator is a binary variable "divorce $i t "$. Observations for which marriages were still in progress at the time of the survey were right censored. For instance, if an individual experienced separation at the third year of marriage, the discrete response will be $\left(\right.$ divorce $_{i 1}$, $_{\text {ivorce }}{ }_{i 2}$, divorce $\left._{i 3}\right)=(0,0,1)$. Someone, whose marriage started three years prior to the year of observation and is still in progress, will be censored and the response vector will be $(0,0,0)$. The discrete-time hazard for year $t$ is the probability that individual $i$ will experience a separation during this year given that no separation has occurred until the previous year, i.e.:

$$
h_{i t}=\operatorname{Pr} o b\left(\operatorname{div} \text { orce }_{i t}=1 \mid \operatorname{div} \text { orce }_{i s}=0, s<t\right)
$$

which is the usual response probability for a binary variable. As is typical in the estimation of such models, I use a logistic regression specification of the following general form:

$$
\log \operatorname{it}\left(h_{i t}\right)=\log \left(\frac{h_{i t}}{1-h_{i t}}\right)=\alpha(t)+\beta^{\prime} X_{i t}
$$

where $\alpha(t)$ is the baseline hazard and $X_{i t}$ a vector of time-varying and fixed covariates. The baseline hazard is specified in the most flexible way, which is $a(t)=a_{1} D_{1}+a_{2} D_{2}+\ldots+a_{g} D_{g}$. In other words, I treat time $t$ as a categorical variable and I define period-specific dummies $D_{j}$ for every period (year) of the marriage. For instance $D_{1}=1$, if individual $i$ is in the first year of marriage and 0 otherwise.

The fixed explanatory variables included in all specifications are: age at first marriage, educational attainment (high-school dropout, high-school graduate, some college, college 
degree or more), a dummy for whether the first birth took place during the marriage or before, state dummies and dummies for the survey years. ${ }^{11}$ The time-varying covariates are: wage inequality, the number of children present in the marriage, dummies for the different ages of children (children between the ages of 1 and 4, 5 to 9, 10 to 14 and 15 and above years old), dummies for every period and calendar year of marriage and other state-level controls that are dependent on the education group of individual $i$ (sex ratio, mean male and female employment rates and wages). I also estimate the model with state-specific time trends. ${ }^{12}$

The inclusion of state dummies implies that identification comes from variation in the state-level time series in inequality and divorce. Hence, the underlying thought is how changes in inequality within a state through time affect the probability of separation. The sex ratio is defined as the ratio of total white men and total white women in the individual's group and roughly proxies for the "local" marriage opportunities. The controls for male and female wages and employment will address concerns about the confounding effects of the declining gender wage gap and of improvements in the labor market opportunities of women relative to men, factors that have been explicitly linked to the incidence of divorce as well as to the widening of the U.S wage structure (Fortin and Lemieux (2000)). Moreover,

\footnotetext{
${ }^{11}$ (i) Age at first marriage enters as a third order polynomial in the specification. Using a set of dummies instead has no substantive effect on the baseline effects. Results are available upon request. (ii) In the survey years 1980, 1985 and 1990 education in the June CPS is coded in years. Only in the 1995 survey education is coded in grades completed or degrees achieved. I define as high school dropouts in the pre- 1995 surveys individuals reporting less than 12 years of schooling and as high-school graduates those reporting 12 years of schooling. Under the classification "some college" are individuals that have completed less than 4 years of college and individuals with associate's degree. Finally, college graduates are individuals that have completed at least 4 years of college.

12 (i) These are interactions of state dummies with a quadratic time trend. (ii) Stevenson (2007) shows that there are significant cohort-of-marriage effects: marriages that started in the 1970s were more unstable than marriages starting in the 1960s, 1980s or 1990s. This finding suggests that the married population has likely underwent significant compositional changes. Controlling for such effects by using five or ten-year cohort-of-marriage dummies has no substantial impact on my findings. Results are available upon request.
} 
since the calculation of inequality excludes males with zero earnings, this will most probably lead to underestimation of the change in inequality over the sample period. The addition of male employment as a control will (at least imperfectly) account for this limitation. Finally, estimation is performed using the available sampling weights. Standard errors are clustered by state but results are robust to other clustering schemes such as by state and year.

\section{Wage Inequality and Marriage Duration}

\subsection{Baseline Results}

Table 1 displays the results (marginal effects) for the baseline specification using CPS data and the standard deviation in weekly log wages as the main measure of male wage dispersion. Column 1 includes only state, year, and period-specific fixed effects in addition to state-level inequality. The marginal effect of inequality is -0.047 and statistically significant. The direction of the estimate implies that increases in wage dispersion have a favorable effect on marital stability. Column 2 adds a series of individual-specific covariates that have been shown to be important determinants of marital dissolution: education, age at first marriage, presence of children and premarital first birth. The estimated coefficient on male inequality negligibly drops (in absolute value) to -0.046 .

Column 3 shows my preferred specification. Here, in addition to the individual characteristics, I also include time-varying state covariates: gender-specific employment rates, log-wages, the sex ratio as well as dummies for the presence of unilateral divorce and property division laws. The estimate of inequality remains strongly significant and equal to -0.041 . 
This estimate suggests that a unit increase in the measure of inequality is associated with an approximately 4 percentage point drop in the separation probability. ${ }^{13}$ Alternatively, an increase in inequality by one standard deviation (0.047) implies a fall in the mean separation probability in a given year $(0.024)$ by $7.8 \%$. To place this number in the context of the declining trend in divorce rates since 1980 (Figure 1), as inequality increased from 0.55 to 0.61 between 1979 and 1990, the average annual separation probability fell from $2.77 \%$ to $1.99 \%$ over the same period. Using the estimate of -0.04 , increases in male wage dispersion can explain roughly $30 \%$ of the decline in the probability of separation since the late 1970s. Turning to the remaining control variables, they generally have the expected sign: separation probability declines with higher age at marriage, higher education, the number of children in the household and the presence of very young children especially when the latter arrive during the marriage as opposed to premaritally. Changes in the legal environment of marriage as well as changes in male employment are not predicted to be significant determinants of marital dissolution. ${ }^{14}$ In contrast, changes in female employment rates as well

\footnotetext{
${ }^{13}$ (i) The logged-odds ratio from this specification is -2.02 which implies an odds ratio of 0.132 . I have also estimated a random effects model that will account for model misspecification due to individual-specific unobserved heterogeneity, commonly referred to as "frailty" in the event history analysis literature. The presence of unobserved heterogeneity can significantly bias the estimated parameters. However, because the baseline hazard is already specified in a flexible way, the magnitude of such potential bias in the nonfrailty (baseline) model can be expected to be rather small. The implied odds ratio from the random effects ("frailty") specification was 0.248 (logged-odds coefficient of -1.393) and statistically significant at $1 \%$ level. (ii) Estimates produced using a probit or a linear model are very similar to the baseline. (iii) I have experimented with limiting the sample to marriages starting within the last 10,5 and 3 years from the survey date. Bringing the window of observation closer to the survey date will likely minimize the chances of recall bias and also that the individual has changed his state of residence relative to the one reported at the survey date. The obtained marginal inequality effects were in the range of -0.051 and -0.062 and statistically significant (with the exception of the 3 year-period were the sample size decreases substantially rending the estimate (-0.06) insignificant). These estimates are in the range of the ones produced by the NLSY79 (Table 3 and Appendix Table 3).

${ }^{14}$ Replacing the single dummy for the presence of unilateral divorce laws in a given state and year with a set of dummies for the years before and after the introduction of the law has no substantive effect on the results. Results are available upon request.
} 
as male wages in the individual's relevant group have a significantly positive effect on the odds of separation, while changes in female wages appear to have no effect. The positive impact of male wages on the female probability of divorce is somewhat counter-intuitive since one would expect women to become more likely to stay married when the labor market prospects of their husbands relatively improve. As detailed in subsequent section, search theory provides a sensible interpretation for this result. Finally, increases in the sex ratio tend to increase the probability of disruption as an oversupply of men relative to women tends to improve female remarriage prospects.

\subsection{Robustness}

Table 2 presents a series of robustness checks for the preferred specification (Table 1, Column 3). In Column 1 I perform a test for selection into marriage. Previous studies suggest than increases in inequality since the late 1970s have led to significant increases in the age at first marriage (Gould and Paserman (2003), Loughran (2002)). ${ }^{15}$ Moreover, individuals who marry later in life tend to have lower probability of divorce (Becker et al. (1977)). While the main specification already controls for the individual age at first marriage and therefore should account for this type of selection, in Column 2 I include inequality in the year prior to marriage in order to address any further concerns. Notice, however, that for this specification the sample needs to be restricted to observations for which inequality in the year prior to the start of the marriage can be calculated. Given the limitations of the March CPS analyzed

\footnotetext{
${ }^{15}$ Gould and Paserman (2003) show that this result holds for all white women regardless of their educational attainment. In fact, the estimated effect of wage inequality on the probability of being single is very similar and highly significant for women with at most a high school degree (marginal effect of 0.250 ) as well as for more educated women (marginal effect of 0.253 ).
} 
in the data section, the estimation of this model results in a sample size reduction. As can be seen, despite the sample cut, the auxiliary inequality term does not significantly affect the separation probability. More importantly, while the size of the coefficient of interest (inequality during the marriage) slightly declines in absolute terms - from -0.041 to -0.034 inequality continues to remain a strong predictor of the propensity to divorce. ${ }^{16}$

In Column 2 I check whether the results are driven by changes in the demographic composition of the male population. For this purpose, I employ as measure of male wage inequality the standard deviation in log weekly residual (on experience and education) wages. ${ }^{17}$ This measure controls for inequality between age and education groups. Clearly, the use of residual, within-group wage inequality yields very similar results.

Another potential concern could be that the impact of male inequality on the likelihood of divorce is inconsistently estimated because of confounding factors that have not been captured by the state and time effects. Two such important candidates are the evolution in female employment and the gender wage gap, which, however, have already been accounted for in the baseline model. I address the potential issue of endogeneity in several ways. First, identification can be threatened if there are other gradually evolving, unobserved factors, such as changes in social norms, that vary within states and are systematically correlated with changes in inequality and divorce. The inclusion of state-specific time trends should

\footnotetext{
${ }^{16}$ The coefficient of contemporaneous inequality when the baseline model is estimated on the restricted sample before the addition of inequality lags is -0.034 with a standard error of 0.014 . Hence, in practice the addition of lagged inequality has no effect on the baseline estimate. In an omitted analysis, I have experimented with adding up to five-year inequality lags corresponding to years prior to the start of the marriage. While the coefficient on contemporaneous inequality is not substantially different from the coefficient reported in Table 2 (Column 1), it is estimated with less precision due to significant reductions in sample size.

${ }^{17}$ For the calculation of residual wages, the variables used are: education (dropout, high school graduate, some college, college degree or higher), experience, experience squared as well as interactions between experience and education.
} 
largely capture these factors. Adding state trends in Column 3, however, changes results very modestly.

Moreover, we might be concerned that the estimated effects are contaminated by reverse causality. One such scenario could be that increases in the probability of separation induce husbands to work more and this in turn lowers the degree of "local" male wage inequality. While existing evidence associates higher separation risk with higher female labor supply (Johnson and Skinner (1986)), to my knowledge there is no empirical evidence linking male employment to divorce. Another possibility is that changes in male wage inequality reflect changing preferences for divorce among men. If divorced men (like unmarried men) have weaker labor force attachment and lower wages than married individuals, then marriage markets with relatively higher numbers of divorced males may display higher overall levels of wage inequality. To address the latter scenario, in Column 4 of Table 2 I reestimate the baseline specification using wage inequality among married men. The estimated coefficient is -0.038 suggesting that any bias due to simultaneity of work and divorce decisions is likely not an important concern.

Finally, I present results from an instrumental variables model where male wage inequality in a given year and state is instrumented by the state's industrial composition in 1960 interacted with year fixed effects. ${ }^{18}$ The rationale is that nationwide factors such as technological change and international trade cause changes in the industrial mix, which have differential

\footnotetext{
${ }^{18}$ The industrial mix in 1960 are the state-level employment shares for ten industries: Agricultural, Forestries, Fishing and Mining, Construction, Manufacturing, Transportation, Communication and other Public Utilities, Wholesale and Retail Trade, Finance, Insurance and Real Estate, Business and Repair Services, Personal Services, Entertainment and Recreation, Professional and Related Services and Public Administration. The employment shares are calculated for white men 16 to 64 years old and not enrolled in school based on a $1 \%$ Census sample.
} 
effects across states due to distinctive state-specific characteristics. For instance, if the share of manufacturing jobs in 1960 in a given state is higher than in another state, then a subsequent deterioration in the manufacturing sector at the national level will likely affect more adversely labor demand in the state that is more manufacturing-intensive. Therefore, the industrial mix in 1960 will subsequently predict changes in the income distribution (Frankel and Gould (2001)). ${ }^{19}$ Furthermore, because the state industrial composition in 1960 does not have a time-varying component, I interact it with year fixed effects. Column 5 presents the second stage results for the baseline specification as well as an F-statistic of 17.11, which suggests that weak instruments is likely not an issue. The result is qualitatively similar to the benchmark and statistically significant albeit the point estimate is somewhat larger in absolute magnitude. As discussed however in the following section, the IV coefficient lies within the range of estimates calculated from the NLSY79 data (Table 3). ${ }^{20}$

Overall, the IV results along with the estimates in Columns 1 through 4 provide strong suggestive evidence that endogeneity is not responsible for the observed relationship between

\footnotetext{
${ }^{19}$ In an omitted analysis but available upon request I have graphed male wage inequality in several years against the predicted inequality based on the industrial composition in 1960. These graphs show that industrial mix in 1960 can remarkably predict the pattern of wage dispersion one, two and three decades later and furthermore, for almost all the years in between. This result suggests that whatever state-specific factors determine the formation or diffusion of certain "structural" phenomena, such as the industrial composition or the wage structure, they tend to be relatively stable over time. While these state-specific characteristics might themselves be correlated with marriage and divorce outcomes, the fact that they have remained stable over the last 30 years suggests that state fixed effects, already included in the baseline model, should account for this potentially endogenous relationship.

${ }^{20}$ The IV estimate is produced using a linear probability model. The OLS analogue of the baseline duration model produces a coefficient of -0.045 with a standard error of 0.013 , which is very close to the -0.041 estimated with the logistic specification. Using a linear IV model allows calculating convential statistics for the validity of my instruments. I have a total of 270 excluded instruments. Hence, for brevity, first stage results are not reported but are available upon request. Other instruments I have experimented with are the federal wage interacted with state fixed effects and the "effective minimum" wage and its square, defined as the difference between $\max \{$ federal wage, state minimum wage $\}$ and the median state wage for males (Lee (1999)). Both produced similar estimates to those presented here and are available upon request. All specifications control for the baseline individual and state covariates as well as state and year effects.
} 
inequality and divorce. Taking together the most conservative estimate of -0.034 and the benchmark effect of -0.04, the results imply that increases in male wage dispersion can explain between $26 \%$ and $30 \%$ of the fall in divorce rates between 1979 and 1990 .

\subsection{Wage Inequality and Divorce: Evidence from the NLSY79}

One limitation of the previous analysis is the absence of information on husband's earnings throughout the marriage. This limitation is important because, first, it may be a source of omitted variable bias and, second, because the presence of significant nonlinear effects of individual income on divorce could render the documented findings a simple statistical artifact. If the relationship between individual income and divorce is concave and these nonlinear terms are omitted from the estimated model, the shift from a more equal to a less equal distribution of income would tend to reduce the probability of divorce even if inequality is not a significant determinant of it (Gravelle (1998), Alesina and La Ferrara (2000)).

To address this concern, I turn to data from the NLSY79. Since the NLSY does not publicly report detailed information on the geographical location of the individual, to increase variability in the measure of inequality, I calculate the latter within the respondent's region of residence, metropolitan status, age and education group. The standard aggregate controls are also calculated within region-metropolitan status-age-education cells. ${ }^{21}$

Column 1 of Table 3 replicates the baseline specification while Column 2 shows the

\footnotetext{
${ }^{21}$ Age groups are defined over 10 year intervals. Education groups are defined as detailed in the Data section. The NLSY79 distinguishes four regions. The metropolitan status (residing or not in a metropolitan area) captures urbanicity. The construction of within group inequality and group-adjusted aggregate covariates assumes that the divorce hazard of a 35 year old high school dropout in a given year is most strongly influenced by changes in demographic and economic conditions in the group of 35-45 year olds that have at most a high school degree and who reside in the same region and share the same metropolitan status as the female respondent.
} 
main estimate when husband's characteristics (education and age at marriage) are explicitly accounted for. Next, Column 3 presents estimates when husband's income along with a quadratic and cubic term are added. The results are reassuring of those found using CPS data. First of all, the stabilizing effect of inequality on the marriage is also present in the NLSY. The coefficient of interest (approximately -0.05) is statistically significant and very similar to the CPS results (Tables 1 and 2) and in particular to the IV estimate. Furthermore, it remains stable when controls for husband's education and age at marriage are introduced. When income and its higher order terms are included, the marginal effect of inequality remains essentially unchanged, while both the linear and the nonlinear terms are not statistically significant. Finally, the findings using the NLSY data are robust to the inclusion of residual wage inequality, inequality in the years prior to marriage as well as region-year interactions (Appendix Table 3). Notice that while the potential bias induced by the "no-moving assumption" imposed in the CPS analysis cannot be precisely evaluated, the stability of the results in the NLSY setting suggests that any such underlying bias does not seem to work in a direction that would produce spurious effects. ${ }^{22}$ Overall, these results reinforce the conclusion that the relationship between inequality and divorce does not appear to reflect omitted characteristics of the spouses and in addition, they indicate that the documented effect is independent and operates conditional on couple characteristics.

\footnotetext{
${ }^{22}$ (i) As a reference point, when wage inequality is solely calculated at the most aggregate level, which is that of region, the marginal effect is -0.063 with a standard error of 0.104 . Hence, the baseline finding is quantitatively robust to this aggregation, but the coefficient is more imprecisely estimated. (ii) Regionyear interactions are interactions between dummies for the four Census regions and dummies for each of the calendar years. (iii) The marginal effects of the remaining covariates are omitted for brevity but are available upon request.
} 


\section{Interpreting the Trends: Potential Explanations}

\subsection{A Search Hypothesis}

The negative relationship between male wage inequality and separation could be consistent with an "on-the-marriage search" hypothesis. As discussed in Loughran (2002) and Gould and Paserman (2003), in a simple marriage search model where single women search among the pool of men characterized by their wages, a mean-preserving spread in the quality distribution of offers can be expected to increase search duration because it raises the expected value of wage offers above the reservation wage. ${ }^{23}$ Consequently, growing wage inequality could increase the duration of search for singles and hence the age at first marriage by increasing the option value of waiting for a better marriage offer. Gould and Paserman (2003) show that indeed inequality can explain $18 \%-29 \%$ of the decline in the marriage rate of $21-30$ years old women between 1970 and 1990.

This idea can be extended to marriage duration in the following way. Suppose an analogous scenario where women at every period of their marriage receive alternative marriage proposals. There are two possible states: they can either stay in their current partnership or switch to another. Hence, at each point in time, they need to compare the value of their current match to the value of their outside option in order to determine whether to exit the current marriage. Moreover, assume that once the woman has entered a new partnership,

\footnotetext{
${ }^{23}$ This result is straightforward under the assumptions of risk-neutrality and of the special case of increasing variance, which is the mean preserving spread. Loughran (2000), though, generalizes the result even in the presence of risk aversion and non-mean-preserving spreads in the wage distribution. In particular, he shows that increasing variance will increase the reservation wage for all the women but those with the lowest initial reservation wages.
} 
she stays there forever. ${ }^{24}$ In this setup, provided that rising inequality is again viewed as an increase in the dispersion of the quality distribution of potential partners, there are two possibilities. Consider for instance the case where the reservation threshold of the woman is above the median. As the offer distribution spreads out, it becomes more likely that the woman will receive an offer above her reservation threshold. In this case, the separation probability would increase ("divorce-inducing" effect). At the same time, however, her option value of waiting also rises, her reservation threshold increases, and consequently her separation probability falls ("inhibiting" effect). If the separation process were costless, then the first effect could dominate. Nevertheless, separation is often very costly particularly when children are present. Therefore, if such non-negligible "switching" costs are involved, then the individual would be even more reluctant to separate, making the second case a stronger possibility. ${ }^{2526}$ In this section, I present several pieces of evidence which, while they do not falsify the search hypothesis, they are consistent with this interpretation.

First, given positive assortative matching, an important element of search is that it is likely to take place within particular marriage markets. Such markets can be defined along

\footnotetext{
${ }^{24}$ This setup resembles the one discussed in Loughran (2001) and Gould and Paserman (2003) in that women face two options: remain single or get married. Once married, though, they stay married forever.

${ }^{25}$ Weiss and Willis (1997) identify three types of costs that are associated with the dissolution of a marriage. First, there are legal costs regarding the divorce process and the division of property. Furthermore, marriagespecific capital, such as knowing the preferences of the spouse, is lost. Lastly, if children are involved, divorce can result in misallocation of public goods, like child care expenditures. For instance, if the custodian parent does not internalize the preferences of the ex-spouse for expenditures on children, the divorce could lead to an inefficiently low level of such expenditures. Also see Becker (1991) for a discussion on the costs of marital dissolution and the extent of "search" during the marriage.

${ }^{26}$ In the context of job search, Hey and McKenna (1979) consider a simple setup - analogous to the one described in the text - where an employed worker has to decide whether to change jobs under the assumption that search is costless but there is a non-negligible switching cost associated with this choice. As expected, the individual will follow a reservation wage rule, where the reservation wage is a function of his current wage. More precisely, under the optimal strategy, the present value of earnings associated with the reservation wage is equal to the present value of earnings associated with the current wage plus the switching cost. Furthermore, it is shown that, as this cost and the probability of getting a job offer increase, the worker becomes more reluctant to move to another job and hence, at each wage rate his reservation wage rises.
} 
three key dimensions: location, race and education. Since the focus has been on the white population and since by the structure of the June CPS the smallest geographic unit of observation is the state of residence, I have already imposed sorting with respect to race and geography. Moreover, the current measure of inequality assumes that women search for second husbands across all educational groups. To further refine this aspect of search, first, I reestimate the baseline model separately for each level of educational attainment of the woman. The estimates in the first half of Panel A (Table 4) indicate that, with the exception of women with some college, women of all educational backgrounds tend to display lower divorce propensities when inequality increases. The effects are, however, strongly pronounced for less-educated women and in particular for high school graduates. For dropouts, while the point estimate is large in absolute magnitude, it is not precisely estimated. For college graduates, the coefficient is negative, smaller in absolute magnitude compared to the estimates for the less-educated groups and not statistically significant. The relatively limited responsiveness in divorce behavior of women with higher educational attainment can be rationalized within the context of a search hypothesis under the presumption that, due to assortative matching in education and due to the positive correlation between education and earnings, women with more education tend to have relatively higher reservation thresholds. As explained above, for women with reservation values above the median, the overall effect of inequality on divorce is theoretically ambiguous: inequality increases the chances of allocating a better match but also raises the reservation wage and thus lowers the probability of separation.

In the second half of Panel A of the same table, I repeat the previous exercise measuring, 
however, inequality by differences across percentiles of the male wage distribution. This decomposition accounts for the stylized fact that wage inequality grew asymmetrically across the wage distribution. The results provide more assertive evidence suggestive of the fact that women search within narrowly defined pools of men. Empirically, the predictions are sharpest for women with low educational attainment. Dropouts, whose search is likely concentrated among low-wage men, respond most dramatically to increasing variance at the bottom half of the wage distribution in the 50th-25th percentile. High schools graduates, on the other hand, while they react to changes throughout the entire distribution, they are most responsive to increases in the 75th-50th percentile rather than at the top of the wage distribution. The results, however, for women with higher education (some college or higher) are inconclusive and neither of the estimates is statistically relevant. ${ }^{27}$

In Panel B (Table 4), I pursue a relatively more parsimonious specification by examining the effect of male inequality within the geographic (state) and education-appropriate group of the woman. ${ }^{28}$ For women with at most a high school degree, increases in within group inequality in the upper half of the wage distribution are associated with large declines in divorce propensities. Changes instead in within-group inequality in the bottom half of the distribution have no discernible effect on divorce behavior. Given that a search hypothesis would imply that women respond to changes in the distribution above their reservation

\footnotetext{
${ }^{27}$ Both sets of results in Panel A are robust to the inclusion of lagged inequality terms as in Table 2 (Column 1). Estimates are slightly attenuated but the main qualitative conclusions strongly remain. Hence, selection does not seem to play a crucial role in explaining the heterogeneous responses of different education groups to growing inequality.

${ }^{28}$ For the analysis using the NLSY79 sample, inequality is calculated within the regional-metropolitalage-educational group of the respondent. Since the region is a very broad geographic area, it is possible to construct reasonably-sized age cells. For the analysis, however, that uses the June CPS data and defines aggregate variables at the state and education level (Table 4), further decomposition into age groups results in state-education-age cells of very low size. For this reason, I choose to construct within state-education adjusted inequality rather than state-education-age within group inequality.
} 
wage, the latter finding is consistent with this prediction. Moreover, in line with the latter interpretation, it appears that the median female reservation threshold for women with lower educational attainment lies close to the median of male wages. ${ }^{29}$ Coefficients for females with more than a high school degree are instead smaller in absolute magnitude, overall insignificant and do not demonstrate a clear response pattern of divorce to changes in wage dispersion.

Second, search theory would generally imply a positive and small coefficient on male wages, since increases in the mean of the distribution increase reservation values less than proportionally (Mortensen (1986), Loughran (2002)). This would consequently suggest a small positive effect of mean male wages on the propensity to separate. In light of this prediction, it is worth noting that the coefficient on mean male wages is positive and significant across all specifications reported in Tables 1 and 2 .

Finally, a search hypothesis would have implications about remarriage. First, it would imply that increases in male wage inequality drive lower separation rates through delays in remarriage. Hence, under this scenario one should observe a negative relationship between inequality experienced throughout the first marriage and the probability to subsequently remarry. Furthermore, if male inequality leads to longer marriage duration through "on-themarriage" search, then the timing of remarriage might be affected as well. In particular, the implication would be that remarriage takes place relatively soon after divorce. In the CPS data, $34 \%$ of the women who were included in the main sample and divorced, remarried within roughly one year from their formal divorce date. In the two years following divorce, the percentage of divorced women who remarry climbs to $55 \% .{ }^{30}$ NLSYS79 data produce

\footnotetext{
${ }^{29}$ These results are analogous to the findings of Loughran (2002).

${ }^{30} \mathrm{I}$ consider these percentages produced by the CPS data as a lower bound for the share of people who enter
} 
very similar statistics. These numbers are not negligible and likely reflect matches that had already started before the first marriage split. Using the NLSY sample, I find that $20 \%$ of individuals whose first marriage ended in divorce had already found another partner by the formal divorce date. This number is slightly higher among those who eventually remarried.

I formally address these two implications using information on the timing of remarriage of divorced women from the baseline June CPS sample. In Table 5, I present estimates from a discrete time duration model along the lines of the specification described in Section 2.2 , where the event of interest is instead the time elapsed between the formal divorce year and the year of the second marriage. The specification controls for the standard set of aggregate controls and additionally for the age at first separation, the duration of the first marriage, education and the presence of children. There are two important covariates of interest: the wage inequality the respondent experienced throughout the first marriage and the level of inequality experienced since the divorce date and until remarriage (or survey year if remarriage never occured).

The estimates suggest that women who experienced higher inequality while married, tend to remarry later. Moreover, the effect is statistically significant. This result is consistent with the idea that increases in wage dispersion induce lower separation rates through delays in remarriage. Interestingly, however, changes in inequality between the time of divorce and remarriage have no significant impact on the probability to remarry. If "search" has already started while the marriage is still in progress and a new partner has been found

new partnerships soon after divorce. This is because there is a consistently increasing trend for cohabitation since the 1970s and it is possible that a number of people who divorce choose simply to cohabitate rather than enter a new legal union. Since the June CPS Supplements only identify formal marriages, the numbers presented may underestimate the proportion of women who had formed new relationships before the legal end or separation date of their first marriage. 
before the first marriage split, then no further post-divorce search would be required and therefore contemporaneous, post-divorce inequality would be redundant. This interpretation is consistent with the observation that changes in contemporaneous inequality have no impact on remarriage. These findings are in line with results by Gould and Paserman (2003) who, in the context of the marriage decision, find that divorced women wait longer to get remarried when there is overall higher male inequality. They do not, however, distinguish between inequality during the marriage and post-divorce. The results from Table 5 suggest what that the former is probably the more relevant margin within the context of a search framework.

To summarize, the evidence presented in this section, while not conclusive, is suggestive of a search channel. As such, it corroborates existing empirical literature supportive of the presence of search during the marriage. In discussing the economics of marriage and divorce, Becker (1991) points out that imperfect information at the time of marriage and the acquisition of additional information during the course of the relationship are important determinants of divorce. As more information is accumulated about one's own spouse as well as one's own outside options, the initial assessment of the quality of the match is continiously revised. In this context, Udry (1981) and White and Booth (1991) find evidence in survey data that individuals' perceptions of their remarriage prospects or of their ability to improve upon their current mate are significant predictors of separation even after controlling for measures of marital satisfaction. Mueller and Pope (1980), who study empirically the relationship between the socioeconomic status of a woman's first and second husband, find that on average there is upward mobility through remarriage and that the length of the first 
marriage is positively correlated with the socioeconomic status of the second husband. ${ }^{31} \mathrm{In}$ a similar context, McKinnish (2007) and South and Lloyd (1995) show that sexual intergration in the workplace as well as the supply of spousal alternatives in the local marriage market can significantly influence the odds of divorce. In the latter study, South and Lloyd (1995) also provide statistics, based on data from the National Survey of Families and Households (19871988), indicating that one-quarter - or perhaps considerably more - of marital disruptions are preceded by the infidelity of the one or the other spouse while the marriage still existed. Even though such statistics for intact marriages cannot be calculated, this estimate is indicative of the possibility that some perception of the availability of desirable outside alternatives is formed during the marriage and that it does influence the value of the partnership and therefore the odds of marital disruption.

\subsection{Changes in Female Wage Inequality}

Given the high correlation between male and female inequality, another explanation for my findings could be that they reflect the role of female inequality on the male search behavior. By the same search argument as for women, female inequality could directly affect marriage duration if men respond to rising female inequality by searching longer for another partner. To test whether changes in female inequality drive the results, I repeat the estimation of the baseline model controlling for female wage dispersion. Because for women the actual work experience is unknown, I use residual wage inequality for both men and women. With this

\footnotetext{
${ }^{31}$ Chiswick and Lehrer's (1990) marital search model delivers the same theoretical prediction. However, they do not have the relevant data to test it.
} 
measure, I should be able to account for selection of women into the labor force at least on the basis of age and education. As shown in Column 6 of Table 2 (and Appendix Table 3 for the NLSY79), male inequality still significantly influences the separation decision. This result does not imply that men are not searching but is rather consistent with the idea that the wage is only a very imperfect predictor of the quality of a woman and hence men could be searching for a partner with criteria other than the wage.

\subsection{Changes in Labor Supply and Household Specialization}

The findings presented so far could also support a scenario where changes in wage dispersion induce changes in family labor supply. Individuals may perceive increasing inequality as an opportunity to reap higher returns when working harder in the labor market. Those earning higher wages have an incentive to increase their labor supply, whereas those with wages very close to the mean who are getting poorer may be induced to work more or less. Furthermore, work hours of married couples have been explicitly linked to divorce (Becker et al. (1977), Tzeng and Mare (1995), Weiss and Willis (1997), Nock (2001)). Although it is difficult to establish causality, descriptive evidence (Johnson (2004)) shows that the incidence of divorce is much greater in households where both spouses are employed rather than just one. Moreover, the work hours of the wife are more highly correlated with marital disruption than the work hours of the husband. Hence, to the extent that time in the labor market competes with marriage-specific time, there could be an effect of wage inequality on the marriage through changes in the pattern of spousal labor supply, intrahousehold bargaining and division of labor. 
To address this potential channel, I use the NLSY79 sample, which provides information on the usual weekly hours worked by the spouses in a given survey year. Table 3 (Columns 4 and 5) presents the marginal effects from the estimation of the baseline hazard model accounting for variation in the labor supply of the two parties during the marital course. In Column 4, I report estimates when the wife is allowed to supply zero hours of work, while in Column 5 I explore the case where both spouses report positive hours. Notice that restricting labor supply to be strictly positive for both spouses implies an additional reduction in sample size. The results convey two main messages. First, the effect of a widening male wage structure is more pronounced (in absolute sense) among couples where both spouses are employed. In this case, the effect is -0.067 and significant at $5 \%$ as compared to the coefficient of -0.048 (Column 4) for couples where the wife has the option of not participating in market work. Second, even after accounting for changes in the spousal labor supply, such changes appear to have no substantial effect on the estimate of inequality, even though variations in the female hours worked have a significantly disruptive effect on the marriage, in line with previous studies. $^{32}$

\footnotetext{
${ }^{32} \mathrm{An}$ alternative interpretation could be that increases in wage dispersion enhance the relative bargaining position of the wife in the household by increasing her option value of waiting for a potentially better offer. In this event, men would work more to make income transfers to the wife in order to keep her in the marriage and women in turn would work less (Chiappori et al. (2002)). These labor supply patterns would be associated with reduced divorce risk. In an omitted analysis that uses March CPS data, I find some evidence consistent with this bargaining argument: increases in male inequality are weakly associated with more work hours by the husband and fewer by the wife. Nevertheless, the results in Columns 4 and 5 of Table 3 suggest that this mechanism lacks amplification power, since variations in spousal labor supply do not explain away the impact of inequality on divorce. These results are available upon request.
} 


\subsection{Changes in Income Uncertainty}

Another argument for the connection between wage inequality and divorce could be that inequality reflects growing income variability and therefore uncertainty. Marriage is a form of consumption insurance whereby couples enter in order to hedge against income risk. If growing wage inequality translates into shocks to household income, then these shocks can affect divorce behavior by altering the returns from marriage (Becker et al. (1977), Hess (2004), Charles and Stephens (2004)). For instance, a positive shock could stabilize the marriage due to an increase in the marital surplus but it could also induce the wife to file for divorce because of the benefits associated with the divorce settlement.

To empirically address the argument that inequality may reflect transitory earnings variability (total earnings or just male earnings variability), it is necessary to distinguish between income shocks within the household as opposed to income volatility outside the marriage. Since the NLSY79 provides information on spousal and family income at every survey date, I can measure per period own household income dispersion using the coefficient of variation. The latter is the ratio of the standard deviation of $(\log )$ household or individual income over the average of that income up to year $t$ of the marriage. To derive a measure of aggregate uncertainty within a respondent's own reference group (as defined by her region, metropolitan area status, age and education), I use the information on individual and household income available in the annual March CPS Supplements, which I match consecutively from 1979 until 2010 following the procedure described in Madrian and Lefgren (1999). Aggregate income volatility is measured by the standard deviation of the change in (log) household or individual income between two consecutive periods in a given geographic-age-education cell. 
Table 3 Columns 6-9 present results using the NLSY79 when measures of aggregate and/or micro (household or individual)-level income volatility are included in the baseline model. In Column 6 I introduce the coefficient of variation calculated using husband's income. This is in addition to spousal log-income and its higher order terms. The respective estimate indicates that greater variability in husband's income significantly increases the odds of divorce. Moreover, this effect operates conditional on changes in male wage dispersion in a woman's given reference group, which remains a powerful predictor of divorce. Interestingly, the two effects work in opposite directions as increases in dispersion in husband's income destabilize the marriage while increases in the group male wage dispersion exert a stabilizing effect. In Column 7, I further supplement the model with a measure of short-run aggregate volatility in male earnings in the respondent's relevant group. Evidently, increasing volatility outside the household has no individually significant effect on the decision to separate and its inclusion in the model only negligibly affects the estimate of inequality. In Columns 8-9 I repeat the same exercise focusing on total household income volatility within the marriage and in the aggregate. The results are largely consistent with the conclusions previously drawn as neither of the two volatility measures can seemingly explain the impact of growing inequality on divorce. ${ }^{33}$

\footnotetext{
${ }^{33}$ Notice that changes in inequality cannot reflect growing uncertainty due to cyclical changes in the economy. In an omitted analysis but available upon request, I have estimated the baseline model using the annual state unemployment rate in lieu of male and female employment rates. The coefficient of inequality remained virtually unchanged.
} 


\subsection{Changes in Social Capital}

The concept of social capital has received considerable attention by academic and policy communities due to its beneficial effects on society, such as transmission of knowledge, development of generalized trust, and its economic ramifications (La Porta et al. (1997), Knack and Keefer (1997)). Rising inequality has been documented as one of the main factors leading to the declines in social capital observed in the last three decades and in particular of the type of capital centered in the community. The latter includes volunteer work and organizational activity (Alesina and La Ferrara (2000), Costa and Kahn (2001)). In order for this mechanism to explain my findings, declines in social capital should be positively related to the incidence of divorce. This would be consistent with the idea that the lack of interpersonal activities due to growing inequality creates difficulties in finding another partner and therefore prolongs the search process. The positive relationship between social capital accumulation and divorce is a testable implication that I address in this section.

To do this, I use data on volunteering, club membership and involvement in community projects to construct a measure of social capital. The data is drawn from the DDB Survey. ${ }^{34}$ The latter provides information about participation in various activities, personal attitude towards social issues as well as basic demographic and geographic information. Participation to social activities is one if the individual participated in any of the above activities over the last year and zero otherwise. This data is organized in state-year means and merged

\footnotetext{
${ }^{34}$ DDB Needham Life Style Survey is an annual cross-sectional study produced by DDB Worldwide that covers the period 1975-1998. It delivers an annual sample of approximately 4000 individuals and contains state identifiers. It is "one of the richest known sources of data on social change in America in the last quarter of the twentieth century" (Putnam in Bowling Alone). While the survey was conducted at an annual basis, the questions regarding volunteering, club membership and participation in community projects were only asked for a limited number of years.
} 
with the share of ever divorced women in the corresponding cell as well as a number of state covariates (female educational attainment, employment rates and wages by gender, sex ratio, median female age at first marriage, presence of unilateral divorce and no-fault property division laws). Information on the stock of divorces is calculated from the June CPS for the years $1985,1990,1995 .^{35}$

Column 1 of Table 6 depicts estimates from a regression of the share of ever-divorced women on the male and female participation rates in social activities, state-level covariates, state and year dummies. The results suggest that the share of ever divorced women is increasing in the share of men participating in social activities and decreasing in the female participation rate. The positive effect of the male participation is theoretically consistent with the scenario described above. However, the estimate is not statistically significant. The state and year effects allow identification to steem from variation in social capital activity and divorce within states over time and therefore unobservable state-specific time-invariant confounding factors are controlled for. However, these results could be suffering from reverse causality if, for instance, divorced people tend to participate more intensively in such activities. In order to reduce this potential simultaneity bias, I construct male and female participation rates among married individuals. The new estimates are presented in Column 2. While the relevant coefficients become smaller in absolute value, neither of them is significant. These results seem to suggest that community-based social capital disaccumulation hasn't likely been an important determinant of divorce in recent years.

\footnotetext{
${ }^{35}$ The share of ever divorced women by state can also be calculated for 1980 . However, there is no data on social capital for that particular survey year.
} 


\section{Conclusion}

A growing literature in economics seeks to uncover the societal implications of increasing wage inequality. The latter has been linked to a number of adverse phenomena: higher crime rates, higher local retail prices and lower investments in social capital (Gould et al. (2002), Alesina and La Ferrara (2000), Frankel and Gould (2001)). This paper contributes by documenting a positive effect of male wage inequality on marriage stability. Whereas previous research by Loughran (2002) and Gould and Paserman (2003) has linked increases in wage dispersion to declines in the age at first marriage - an important determinant of divorce - I show that changes in the wage structure have also played a distinct role in the evolution of divorce rates over the recent decades. This relationship is not primarily driven by changes in female wage dispersion, varying patterns of spousal labor supply, transitory increases in income volatility or changes in social capital accumulation. The findings instead, although they do not constitute explicit evidence of an "on-the-marriage" search hypothesis, they are consistent with this interpretation.

Furthermore, this study importantly speaks to the literature on family formation and dissolution. Amid concerns about the adverse effects of rising inequality on society, the latter has been proven to be an important deterrent of marital disruption. This contribution is relevant in light of discussions about the adverse implications of divorce for the socieoeconomic and emotional well-being of women and children and a growing interest in finding ways to promote and protect family life. The positive effect on family stability should also be taken into account when evaluating the overall welfare effects on society of the recent trends in wage dispersion. 


\section{References}

[1] Alesina, Alberto and Eliana La Ferrara (2000): "Participation in Heterogeneous Communities," Quarterly Journal of Economics, Vol. 115, No. 3, pp. 847 - 904

[2] Autor, David H., Lawrence F. Katz and Melissa S. Kearney (2008): "Trends in U.S. Wage Inequality: Re-Assessing the Revisionists," Review of Economics and Statistics, Vol. 90, No. 2, pp. $300-323$

[3] Bailey, Martha (2006): "More Power to the Pill: The Impact of Contraceptive Freedom on Women's Lifecycle Labor Supply," Quarterly Journal of Economics, Vol. 121, No. 1, pp. $289-320$

[4] Becker, Gary S., Elisabeth M. Landes and Robert T. Michael (1977): "An Economic Analysis of Marital Instability," Journal of Political Economy, Vol. 85, No. 6, pp. 1141 $-1188$

[5] Becker, Gary S. (1991): "A Treatise on the Family," Enlarged Edition, Cambridge: Harvard University Press.

[6] Bumpass, Larry L. and Teresa Castro Martin (1987): "Recent Trends and Differentials in Marital Disruption," CDE Working Paper 87-20

[7] Charles, Kerwin and Melvin Stephens (2004): "Job Displacement, Disability and Divorce," Journal of Labor Economics, Vol. 22, No. 2, pp. 489 - 522

[8] Chiappori, Pierre-André, Bernard Fortin and Guy Lacroix (2002): "Household Labor Supply, Sharing Rule and the Marriage Market," Journal of Political Economy, Vol. 110, No. 1, pp. $37-72$

[9] Chiswick, Carmel U. and Evelyn L. Lehrer (1990): "On Marriage-Specific Human Capital: Its Role as a Determinant of Remarriage," Journal of Population Economics, Vol. 3, No. 3, pp. 193-213

[10] Costa, Dora L. and Matthew E. Kahn (2003): "Understanding the American Decline in Social Capital, 1952-1998," Kyklos, Vol. 56, No. 1, pp. 17 - 46

[11] Fortin, Nicole and Thomas Lemieux (2000): “Are Women's Wage Gains Men's Losses? A Distributional Test," American Economic Review, Vol. 90, No. 2, pp. 456-460

[12] Frankel, David M. and Eric D. Gould (2001): “The Retail Price of Inequality," Journal of Urban Economics, Vol. 49, No. 2, pp. 219 - 239

[13] Goldin, Claudia and Robert Margo (2002): "The Great Compression: The Wage Structure in the United States at Mid Century," Quarterly Journal of Economics, Vol. 107, No. 1, pp. 1 - 34

[14] Goldstein, Joshua R. (1999): "The Leveling of Divorce in the United States," Demography, Vol. 36, No. 3, pp. 409-414 
[15] Gould, Eric D., Bruce A. Weinberg and David B. Mustard (2002): "Crime and Local Labor Market Opportunities in the United States," Review of Economics and Statistics, Vol. 84, No. 1, pp. 45 - 61

[16] Gould, Eric D. and Daniele M. Paserman (2003): "Waiting for Mr. Right: Rising Inequality and Declining Marriage Rates," Journal of Urban Economics, Vol. 53, No. 2, pp. $257-281$.

[17] Gravelle, H. (1998): "How Much of the Relation Between Population Mortality and Unequal Distribution of Income is a Statistical Artifact," British Medical Journal, Vol. XVI, pp. 382-385

[18] Hess, Gregory D. (2004): "Marriage and Consumption Insurance: What's Love Got to Do with It?," Journal of Political Economy, Vol. 112, No. 2, pp. 290 - 318

[19] Hey, John D. and Chris J. McKenna (1979): "To Move or Not to Move?," Economica, Vol. 46, No. 182, pp. 175 - 185

[20] Johnson, John H. (2004): "Do Long Hours Contribute to Divorce?," Topics in Economic Analysis and Policy, Vol. 4, No. 1, Article 24

[21] Johnson, William R and Jonathan Skinner (1986): "Labor Supply and Marital Separation," American Economic Review, Vol. 76, No. 3, pp. 455-469

[22] Juhn, Chinhui, Kevin M. Murphy, and Brooks Pierce (1993): "Wage Inequality and the Rise in Returns to Skill," Journal of Political Economy, Vol. 101, No. 3, pp. 410 - 442.

[23] Katz, Lawrence F. and Kevin M. Murphy (1992): "Changes in Relative Wages, 1963 1987: Supply and Demand Factors," Quarterly Journal of Economics, Vol. 107, No. 1, pp. $35-78$

[24] Knack, Stephen. and Philip Keefer (1997): "Does Social Capital Have an Economic Payoff? A Cross-County Investigation," Quarterly Journal of Economics, Vol. 112, No. 4, pp. $1251-1288$

[25] La Porta, Rafael, Florencio Lopez-de-Silanes, Andrei Schleifer and Robert W. Vishny (1997): "Trust in Large Organizations," American Economic Review, Vol. 82, No. 2, pp. $333-338$

[26] Lee, David S. (1999): "Wage Inequality in the United States During the 1980s: Rising Dispersion or Falling Minimum Wage," Quarterly Journal of Economics, Vol. 114, No. 3, pp. 977-1023

[27] Loughran, David S.(2002): "The Effect of Male Wage Inequality on Female Age at First Marriage," Review of Economics and Statistics, Vol. 84, No. 2, pp. 237 - 251.

[28] Madrian, Brigitte C. and Lars John Lefgren (1999): "A Note on Longitudinally Matching Current Population Survey (CPS) Respondents," NBER Paper No. T0247. 
[29] Martin, Steven P. (2006): “Trends in Marital Dissolution by Women's Education in the United States," Demographic Reasearch, Vol. 15, No. 20, pp. 537 - 560

[30] McKinnish, Terra G. (2007): "Sexually Integrated Workplaces and Divorce: Another Form of On-the-Job Search," Journal of Human Resources, Vol. 42, No. 2, pp. 331 352

[31] Mortensen, Dale (1986): "Job Search and Labor Market Analysis," in O. Ashenfelter and R. Layard (EDS.), Handbook of Labor Economics, Vol 2, pp. 849-866

[32] Mueller, Charles W and Hallowell Pope (1980): "Divorce and Female Remarriage Mobility: Data on Marriage Matches after Divorce for White Women," Social Forces, Vol. 58, No. 3, pp. 726-738

[33] Nock, Steven L. (2001): "The Marriage of Equally Dependent Spouses," Journal of Family Issues, Vol. 22, No. 6, pp. 755 - 775.

[34] South, Scott and Kim Lloyd (1995): "Spousal Alternatives and Marital Dissolution," American Sociological Review, Vol. 60, No. 1, pp. 21 - 35.

[35] Stevenson, Betsey and Justin Wolfers (2007): "Marriage and Divorce: Changes and their Driving Forces," Journal of Economic Perspectives, Vol. 21, No. 2, pp. 27-52.

[36] Sweeney, M. M. and Phillips, J. A. (2004): "Understanding Racial Differences in Marital Disruption: Recent Trends and Explanations," Journal of Marriage and Family, Vol. 66, No. 3, pp. 639-650.

[37] Tzeng, J. M. and R. D. Mare (1995): "Labor-Market and Socioeconomic Effects on Marital Stability," Social Science Research, Vol. 24, No. 3, pp 329-351

[38] Udry, J. Richard (1981): "Marital Alternatives and Marital Disruption," Journal of Marriage and the Family, Vol. 43, No. 4, pp. 889-897.

[39] Weiss, Yoram and Robert J. Willis (1997): "Match Quality, New Information, and Marital Dissolution," Journal of Labor Economics, Vol. 15, No. 1, pp. 293-329

[40] White, Lynn and Alan Booth (1991): "Divorce over the Life Course: The Role of Marital Happiness," Journal of Family Issues, Vol. 12, No. 1, pp. 5-21. 
Figure 1: Trends in Male Wage Inequality and Separation Rate

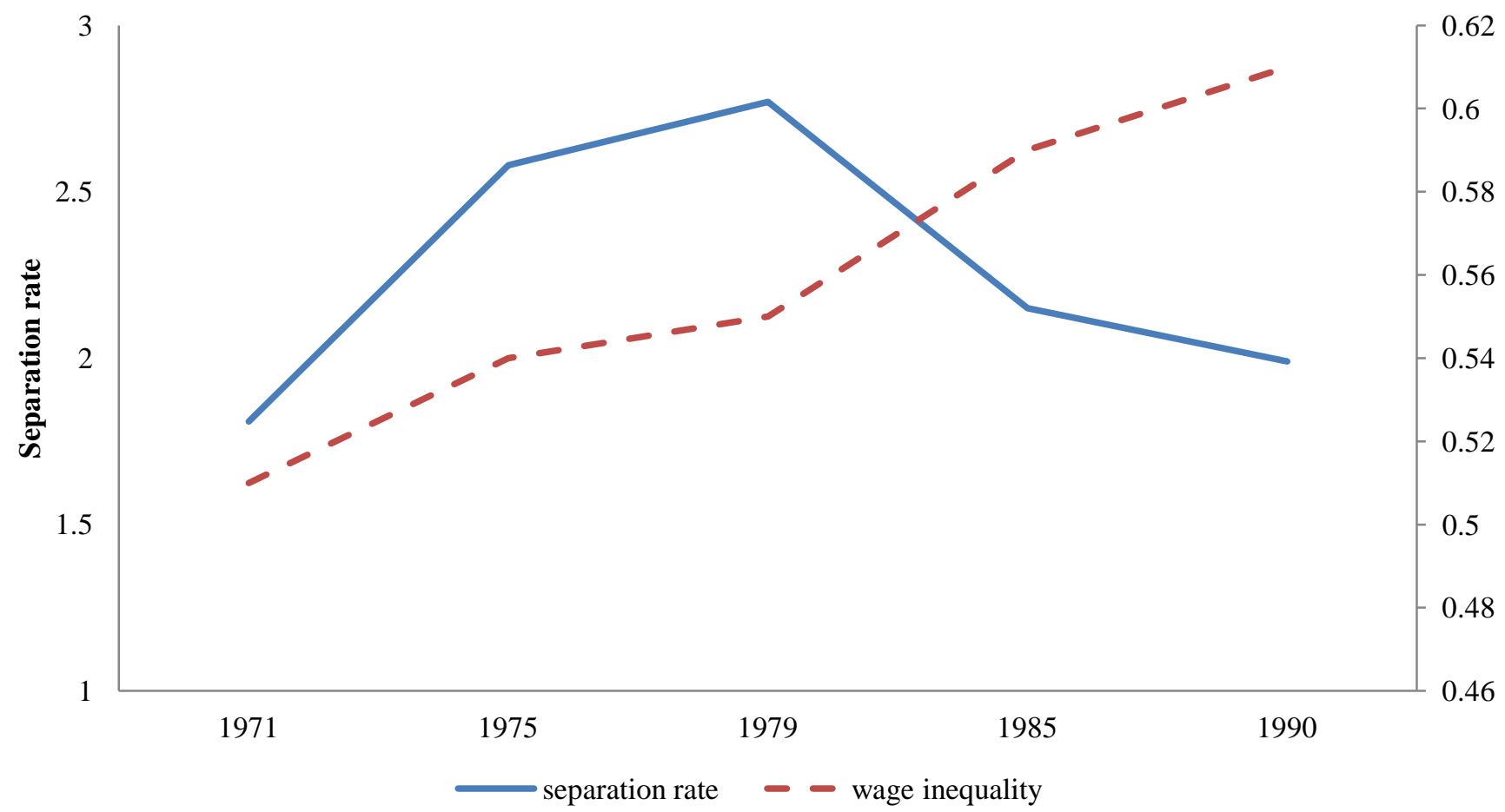

Source: Author's calculations from the June and March Supplements of the CPS. The separation rate is the percentage of first marriages ending in separation in a given year $(1971,1975,1979,1985,1990)$.

Figure 2: Change in Inequality \& Divorce 1980-1990

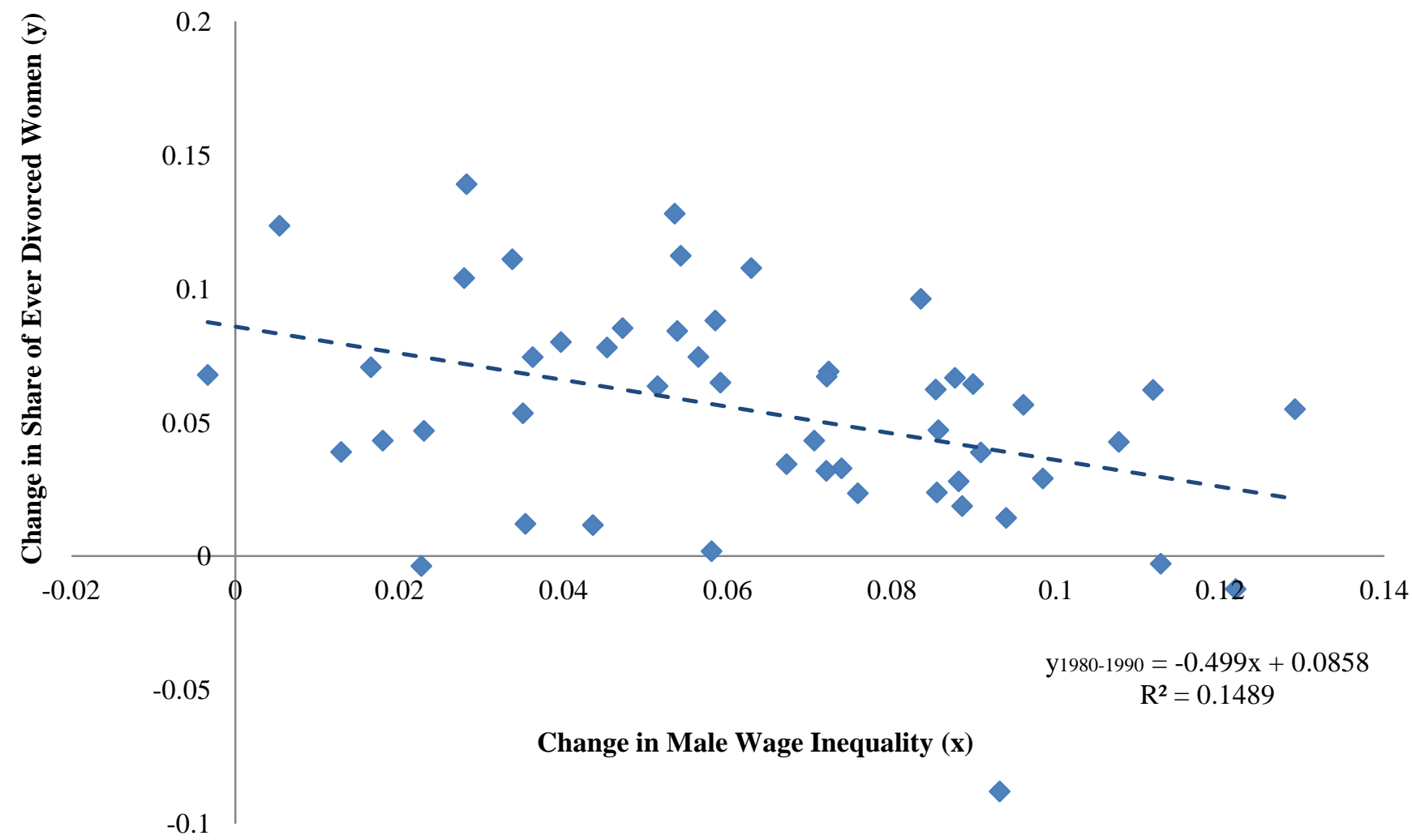

Source: Author's calculations from the June and March Supplements of the CPS $(1980,1990)$. The stock of ever divorced women measures the fraction of ever-married white women 21 to 55 years old who were interviewed in 1980, 1990 and reported that they had separated at any point prior to or at the survey date. 
Dependent Variable $=1$,

\begin{tabular}{|c|c|c|c|}
\hline & (1) & (2) & (3) \\
\hline \multirow[t]{2}{*}{ Male wage Inequality } & -0.047 & -0.046 & -0.041 \\
\hline & $(0.012)^{* * *}$ & $(0.011)^{* * *}$ & $(0.011)^{* * *}$ \\
\hline \multirow[t]{2}{*}{ Age at first marriage } & & -0.018 & -0.018 \\
\hline & & $(0.006)^{* * *}$ & $(0.006)^{* * *}$ \\
\hline \multirow[t]{2}{*}{ Dropout } & & 0.013 & 0.025 \\
\hline & & $(0.006)^{* *}$ & $(0.005)^{* * *}$ \\
\hline \multirow[t]{2}{*}{ High school graduate } & & 0.008 & 0.016 \\
\hline & & $(0.001)^{* * *}$ & $(0.003)^{* * *}$ \\
\hline \multirow[t]{2}{*}{ Some college } & & 0.007 & 0.007 \\
\hline & & $(0.001)^{* * *}$ & $(0.001)^{* * *}$ \\
\hline \multirow[t]{2}{*}{ Number of children } & & -0.004 & -0.004 \\
\hline & & $(0.0009)^{* * *}$ & $(0.0009)^{* * *}$ \\
\hline \multirow[t]{2}{*}{ First child born prior to marriage } & & 0.023 & 0.022 \\
\hline & & $(0.002)^{* * *}$ & $(0.002)^{* * *}$ \\
\hline \multirow[t]{2}{*}{ Children ages 1-4 in hhd } & & -0.004 & -0.004 \\
\hline & & $(0.0009)^{* * *}$ & $(0.001)^{* * *}$ \\
\hline \multirow[t]{2}{*}{ Children ages 5-9 in hhd } & & 0.0004 & 0.0004 \\
\hline & & $(0.001)$ & $(0.001)$ \\
\hline \multirow[t]{2}{*}{ Children ages $10-14$ in hhd } & & -0.002 & -0.002 \\
\hline & & $(0.001)$ & $(0.001)$ \\
\hline \multirow{2}{*}{ Children ages 15plus in hhd } & & -0.004 & -0.004 \\
\hline & & $(0.002)^{*}$ & $(0.002)$ \\
\hline \multirow[t]{2}{*}{ Mean male state wage } & & & 0.013 \\
\hline & & & $(0.005)^{* * *}$ \\
\hline \multirow[t]{2}{*}{ Mean female state wage } & & & -0.011 \\
\hline & & & $(0.008)$ \\
\hline \multirow[t]{2}{*}{ Mean male state employment } & & & 0.004 \\
\hline & & & $(0.011)$ \\
\hline \multirow[t]{2}{*}{ Mean female state employement } & & & 0.020 \\
\hline & & & $(0.010)$ \\
\hline \multirow[t]{2}{*}{ State sex ratio } & & & 0.005 \\
\hline & & & $(0.001)^{* * *}$ \\
\hline \multirow[t]{2}{*}{ Unilateral divorce laws } & & & -0.003 \\
\hline & & & $(0.002)$ \\
\hline \multirow[t]{2}{*}{ Property division laws } & & & 0.003 \\
\hline & & & $(0.002)$ \\
\hline Mean Separation Rate & 0.024 & 0.024 & 0.024 \\
\hline Mean male wage inequality & 0.53 & 0.54 & 0.55 \\
\hline Survey year \& period-specific dummies & Yes & Yes & Yes \\
\hline State \& year fixed effects & Yes & Yes & Yes \\
\hline Marriage-year observations & 213195 & 213195 & 213195 \\
\hline
\end{tabular}

Coefficients are marginal effects of the explanatory variables on the per period probability of separation using a discrete time duration model. Sample includes white women 21 to 55 at survey date, who got married at the age of 21 or later. Only first marriages are considered. Male wage inequality is the standard deviation in log weekly wages in a state for full-time, full-year white males ages males ages 16 to 64. Estimates are weighted using the provided sampling weights. Standard errors (parentheses) are clustered by state. $* * *, * *, *$ indicate significance at $1 \%, 5 \%$ and $10 \%$ respectively. 
Table 2: The effect of male wage inequality on marriage duration - Robustness (June CPS)

\begin{tabular}{|c|c|c|c|c|c|c|}
\hline \multirow[t]{2}{*}{ Dependent Variable $=1$, } & \multicolumn{6}{|c|}{ if separation takes place in a given year } \\
\hline & (1) & (2) & (3) & (4) & (5) - IV & (6) \\
\hline \multirow[t]{2}{*}{ Male wage inequality } & -0.034 & & -0.045 & & -0.059 & \\
\hline & $(0.015)^{* *}$ & & $(0.013) * * *$ & & $(0.025)^{* *}$ & \\
\hline \multirow[t]{2}{*}{ Male wage inequality 1 year prior } & -0.003 & & & & & \\
\hline & $(0.015)$ & & & & & \\
\hline \multirow[t]{2}{*}{ Residual male wage inequality } & & -0.041 & & & & \\
\hline & & $(0.014)^{* * *}$ & & & & \\
\hline \multirow[t]{2}{*}{ Male wage inequality: married men } & & & & -0.038 & & \\
\hline & & & & $(0.011)^{* * *}$ & & \\
\hline \multirow[t]{2}{*}{ Residual male wage inequality } & & & & & & -0.038 \\
\hline & & & & & & $(0.015)^{* * *}$ \\
\hline \multirow{2}{*}{ Residual female wage inequality } & & & & & & -0.012 \\
\hline & & & & & & $(0.020)$ \\
\hline \multirow[t]{2}{*}{ Mean male wage } & 0.012 & 0.012 & 0.012 & 0.013 & 0.013 & 0.012 \\
\hline & $(0.005)^{* *}$ & $(0.005)^{* *}$ & $(0.005)^{* *}$ & $(0.005)^{* *}$ & $(0.007)^{* *}$ & $(0.005)^{* *}$ \\
\hline $\mathrm{F}(270,1228)=$ & & & & & 17.11 & \\
\hline Hansen $\mathrm{J}$ statistic $\mathrm{p}$-value $=$ & & & & & 0.373 & \\
\hline Other individual \& state covariates & Yes & Yes & Yes & Yes & Yes & Yes \\
\hline Period-spedific dummies & Yes & Yes & Yes & Yes & Yes & Yes \\
\hline State \& year fixed effects & Yes & Yes & Yes & Yes & Yes & Yes \\
\hline State-specific quadratic time trend & No & No & Yes & No & No & No \\
\hline Marriage-year observations & 184656 & 213195 & 213195 & 213195 & 213195 & 213195 \\
\hline
\end{tabular}


Table 3: The effect of male wage inequality on marriage duration - NLSY79

\section{Dependent Variable $=1$,}

Male wage inequality

Husband's income

Husband's income: squared term

Husband's income: cubic term

Wife's weekly hours of work

Husband's weekly hours of work

Husband's income variability

Household income

Household income variability

Aggregate male income variability

Aggregate household income variability

$\begin{array}{ccccc}\mathbf{( 1 )} & \underline{\mathbf{( 2 )}} & \underline{\mathbf{( 3 )}} & \underline{\mathbf{( 4 )}} & \underline{\mathbf{( 5 )}} \\ -0.046 & -0.054 & -0.052 & -0.048 & -0.067 \\ (0.027)^{*} & (0.026)^{* *} & (0.026)^{* *} & (0.025)^{*} & (0.032)^{* *} \\ & & -0.019 & -0.009 & -0.006 \\ & & (0.031) & (0.031) & (0.036) \\ & & 0.002 & 0.001 & 0.0002 \\ & (0.004) & (0.004) & (0.004) \\ & & -0.000 & -0.000 & 0.000 \\ & (0.000) & (0.000) & (0.000) \\ & & 0.0002 & 0.0003 \\ & & (0.0000)^{* * *} & (0.0001)^{* * *} \\ & & 0.000 & 0.000 \\ & & & (0.000) & (0.000)\end{array}$
$0.000)$
$(0.000)$

(6) (7)

0.05

$(0.03) *$

0.05

(0.089)

$-0.005$

(0.01)

0.0002

(0.0004)

001)***

(8)

$-0.054 \quad-0.061$

$\begin{array}{ll}-0.054 & -0.061 \\ (0.034) & (0.034) *\end{array}$

$(0.029) * \quad(0.034)$

$-0.009$

(0.037)

0.0007

(0.004)

$-0.000$

(0.000)

(0.000)

$-0.004$

(0.037)

0.000

(0.004)

0.000

(0.000)

$(0.022)^{*}$

.023)*

$\begin{array}{cc}0.001 & 0.001 \\ (0.001) & (0.001) \\ 0.019 & 0.012 \\ (0.012) & (0.014)\end{array}$

$-0.0009$

(0.005)

Wife's weekly hours of work

Wifes' s characteristics

Husband's characteristics

Aggregate covariates

Period-specific dummies

Region \& year fixed effects

Region-year interactions

$\begin{array}{ccc}\text { Yes } & \text { Yes } & \text { Yes } \\ \text { No } & \text { Yes } & \text { Yes } \\ \text { Yes } & \text { Yes } & \text { Yes } \\ \text { Yes } & \text { Yes } & \text { Yes } \\ \text { Yes } & \text { Yes } & \text { Yes } \\ \text { No } & \text { No } & \text { No } \\ 7160 & 6922 & 6922\end{array}$

$$
>=0
$$

Yes

Yes

Yes

Yes

Yes

No

6855

$>0$
Yes
Yes
Yes
Yes
Yes
No
5857

Yes
Yes
Yes
Yes
Yes
No
5944

Yes
Yes
Yes
Yes
Yes
No
5732

$\begin{array}{cc}\text { Yes } & \text { Yes } \\ \text { Yes } & \text { Yes } \\ \text { Yes } & \text { Yes } \\ \text { Yes } & \text { Yes } \\ \text { Yes } & \text { Yes } \\ \text { No } & \text { No } \\ 5773 & 5506\end{array}$

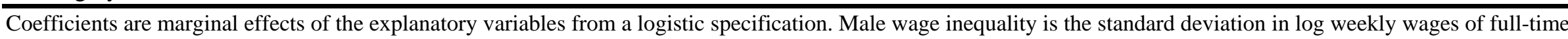

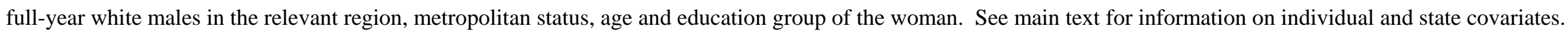

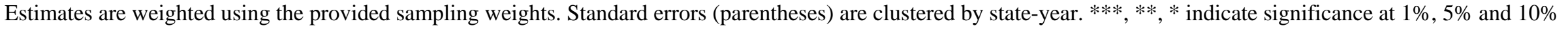
respectively. 
Table 4: The effect of male wage inequality on marriage duration - A Search Hypothesis (June CPS)

\section{Dependent Variable = 1, if separation takes place in a given year}

\begin{tabular}{|c|c|c|c|c|c|c|c|}
\hline \multicolumn{8}{|c|}{ A. Male wages calculated on the full sample (by state-year cells) } \\
\hline \multirow{3}{*}{ Male wage inequality } & Dropout & & High-School & Some College & & College & \\
\hline & $\begin{array}{l}-0.088 \\
(0.07)\end{array}$ & & $\begin{array}{c}-0.106 \\
(020 * *\end{array}$ & 0.013 & & -0.019 & \\
\hline & Dropout & & High-School & Some College & & College & \\
\hline 90-75 difference & $\begin{array}{l}-0.037 \\
(0.027)\end{array}$ & & $\begin{array}{c}-0.031 \\
(0.015)^{* *}\end{array}$ & $\begin{array}{l}-0.001 \\
(0.017)\end{array}$ & & $\begin{array}{l}-0.009 \\
(0.009)\end{array}$ & \\
\hline 75-50 difference & $\begin{array}{l}-0.054 \\
(0.05)\end{array}$ & & $\begin{array}{c}-0.049 \\
(0.021)^{* *}\end{array}$ & $\begin{array}{c}0.022 \\
(0.014)\end{array}$ & & $\begin{array}{c}0.018 \\
(0.011)\end{array}$ & \\
\hline 50-25 difference & $\begin{array}{c}-0.092 \\
(0.039)^{* *}\end{array}$ & & $\begin{array}{c}-0.035 \\
(0.018)^{* *}\end{array}$ & $\begin{array}{l}0.0004 \\
(0.019)\end{array}$ & & $\begin{array}{l}-0.012 \\
(0.01)\end{array}$ & \\
\hline \multirow[t]{2}{*}{ 25-10 difference } & $\begin{array}{c}-0.012 \\
(0.032)\end{array}$ & & $\begin{array}{c}-0.026 \\
(0.011)^{* *}\end{array}$ & $\begin{array}{c}0.011 \\
(0.012)\end{array}$ & & $\begin{array}{l}0.0006 \\
(0.008)\end{array}$ & \\
\hline & \multicolumn{6}{|c|}{ B. Male wages calculated within state, education, year cells } & \\
\hline 90-75 difference & $\begin{array}{c}-0.035 \\
(0.039)\end{array}$ & $\begin{array}{c}-0.04 \\
(0.018)^{* *}\end{array}$ & $\begin{array}{l}-0.007 \\
(0.01)\end{array}$ & $\begin{array}{l}-0.002 \\
(0.005)\end{array}$ & 90-50 difference & $\begin{array}{c}-0.047 \\
(0.027)^{*}\end{array}$ & $\begin{array}{c}-0.034 \\
(0.009)^{* * *}\end{array}$ \\
\hline 75-50 difference & $\begin{array}{c}-0.063 \\
(0.032)^{* *}\end{array}$ & $\begin{array}{c}-0.028 \\
(0.015)^{*}\end{array}$ & $\begin{array}{l}-0.013 \\
(0.015)\end{array}$ & $\begin{array}{c}0.001 \\
(0.007)\end{array}$ & & & \\
\hline 50-25 difference & $\begin{array}{l}-0.026 \\
(0.027)\end{array}$ & $\begin{array}{l}-0.006 \\
(0.012)\end{array}$ & $\begin{array}{c}0.025 \\
(0.016)\end{array}$ & $\begin{array}{c}0.014 \\
(0.007)^{* *}\end{array}$ & 50-10 difference & $\begin{array}{c}0.008 \\
(0.023)\end{array}$ & $\begin{array}{l}-0.005 \\
(0.010)\end{array}$ \\
\hline 25-10 difference & $\begin{array}{c}0.026 \\
(0.027)\end{array}$ & $\begin{array}{l}-0.003 \\
(0.013)\end{array}$ & $\begin{array}{l}0.015^{*} \\
(0.009)\end{array}$ & $\begin{array}{l}-0.009 \\
(0.006)\end{array}$ & & & \\
\hline Marriage-year observations & 14076 & 71013 & 54003 & 73464 & & 14076 & 71013 \\
\hline
\end{tabular}

Coefficients are marginal effects from a logistic specification (see notes of Table 1). All specifications control for standard individual and state characteristics, periodspecific dummies, state and year effects. Standard errors (parentheses) are clustered by state. All specifications are weighted using the provided sampling weights. $* * *, * *, *$ indicate significance at $1 \%, 5 \%$ and $10 \%$ respectively. 
Table 5: Male wage inequality and remarriage

\begin{tabular}{lcccc}
\hline \hline Dependent Variable=1, & \multicolumn{4}{c}{ if remarriage takes place in a given year } \\
\hline & $\mathbf{( 1 )}$ & $\mathbf{( 2 )}$ & $\mathbf{( 3 )}$ & $\mathbf{( 4 )}$ \\
Contemporaneous wage inequality & 0.092 & & 0.118 & 0.138 \\
& $(0.105)$ & & $(0.113)$ & $(0.129)$ \\
Wage inequality during the marriage & & -0.236 & -0.254 & -0.268 \\
& & $(0.108)^{* *}$ & $(0.116)^{* *}$ & $(0.132)^{* *}$ \\
Other individual \& state covariates & Yes & Yes & Yes & Yes \\
State and year fixed effects & Yes & Yes & Yes & Yes \\
State-specific quadratic time trends & No & No & No & Yes \\
Remarriage-year observations & 17894 & 17894 & 17894 & 17894 \\
\hline
\end{tabular}

Coefficients are marginal effects of the explanatory variables on the per period probability of remarriage using a discrete time duration model. Sample includes divorced white women, who first got married at 21 or later. Contemporaneous wage inequality is the the inequality experienced after first divorce and until remarriage (or survey year). See text for a list of covariates. Standard errors (parentheses) are clustered by state. ${ }^{* *}$ indicate significance at $5 \%$.

Table 6: Changes in Social Capital and Divorce (DDB Life-Style Survey \& June CPS)

\begin{tabular}{|c|c|c|}
\hline Dependent Variable: & \% ever div & \\
\hline & (1) & (2) \\
\hline Male participation in social activities & 0.031 & \\
\hline & $(0.024)$ & \\
\hline Female participation in social activities & -0.051 & \\
\hline & $(0.028)^{*}$ & \\
\hline Male participation in social activities & & 0.016 \\
\hline (married population) & & $(0.023)$ \\
\hline Female participation in social activities & & -0.033 \\
\hline (married population) & & $(0.025)$ \\
\hline Other state covariates: & & \\
\hline Median age at first marriage & Yes & Yes \\
\hline Presence of unilateral divorce laws & Yes & Yes \\
\hline$\%$ females with high school, some college, college education & Yes & Yes \\
\hline Mean male \& female employment rate & Yes & Yes \\
\hline Mean male \& female hourly wages & Yes & Yes \\
\hline Sex ratio & Yes & Yes \\
\hline State \& Year dummies & Yes & Yes \\
\hline Observations & 144 & 144 \\
\hline
\end{tabular}

Data is aggregated in state-year means. Dependent variable refers to the share of ever divorced white women 21-55 years old in a given state in 1985, 1990, 1995 (June CPS). Participation in social activities refers to the share of people 21-55 years old that have done volunteer work, participated in a community project or participated in a club meeting over the last 12 months (DDB Life Style Survey). Estimates are weighted by the state population of white ever-divorced females 21-55 years old. Standard errors are clustered by state-year. ***, **, * indicate significance at $1 \%, 5 \%$ and $10 \%$ respectively. 
Appendix Table 1: March CPS Years

\begin{tabular}{|c|c|c|c|c|c|}
\hline State & \multicolumn{2}{|c|}{ Years with Available Info } & State & \multicolumn{2}{|c|}{ Years with Available Info } \\
\hline$\overline{\text { Alabama }}$ & $1965-1967$ & $1977-2010$ & $\overline{\text { New }}$ Mexico & $1965-1967$ & $1977-2010$ \\
\hline Alaska & $1965-1967$ & $1977-2010$ & New York & \multicolumn{2}{|c|}{1965 - 2010} \\
\hline Arizona & $1965-1967$ & $1977-2010$ & North Carolina & $1965-1967$ & $1972-2010$ \\
\hline Arkansas & $1965-1967$ & $1977-2010$ & North Dakota & 1965 - 1967 & $1977-2010$ \\
\hline California & \multicolumn{2}{|c|}{$1965-2010$} & Ohio & \multicolumn{2}{|c|}{$1965-2010$} \\
\hline Colorado & $1965-1967$ & $1977-2010$ & Oklahoma & $1965-1967$ & $1977-2010$ \\
\hline Connecticut & \multicolumn{2}{|c|}{$1965-2010$} & Oregon & $1965-1972$ & $1977-2010$ \\
\hline Delaware & $1965-1967$ & $1977-2010$ & Pennsylvania & \multicolumn{2}{|c|}{$1965-2010$} \\
\hline District of Columbia & \multicolumn{2}{|c|}{$1965-2010$} & Rhode Island & $1965-1967$ & $1977-2010$ \\
\hline Florida & \multicolumn{2}{|c|}{$1965-2010$} & South Carolina & $1965-1967$ & $1977-2010$ \\
\hline Georgia & $1965-1972$ & $1977-2010$ & South Dakota & 1965 - 1967 & $1977-2010$ \\
\hline Hawaii & $1965-1967$ & $1977-2010$ & Tennessee & $1965-1972$ & $1977-2010$ \\
\hline Idaho & 1965 - 1967 & $1977-2010$ & Texas & \multicolumn{2}{|c|}{$1965-2010$} \\
\hline Illinois & \multicolumn{2}{|c|}{$1965-2010$} & Utah & $1965-1967$ & $1977-2010$ \\
\hline Indiana & \multicolumn{2}{|c|}{$1965-2010$} & Vermont & $1965-1967$ & $1977-2010$ \\
\hline Iowa & $1965-1967$ & $1977-2010$ & Virginia & $1965-1967$ & $1977-2010$ \\
\hline Kansas & $1965-1967$ & $1977-2010$ & Washington & $1965-1967$ & $1977-2010$ \\
\hline Kentucky & $1965-1972$ & $1977-2010$ & West Virginia & $1965-1972$ & $1977-2010$ \\
\hline Louisiana & $1965-1972$ & $1977-2010$ & Wisconsin & $1965-1967$ & $1977-2010$ \\
\hline Maine & $1965-1967$ & $1977-2010$ & Wyoming & $1965-1967$ & $1977-2010$ \\
\hline Maryland & $1965-1972$ & $1977-2010$ & & & \\
\hline Massachussetts & $1965-1967$ & $1977-2010$ & & & \\
\hline Michigan & $1965-1967$ & $1977-2010$ & & & \\
\hline Minnesota & $1965-1967$ & $1977-2010$ & & & \\
\hline Mississippi & $1965-1967$ & $1977-2010$ & & & \\
\hline Missouri & $1965-1972$ & $1977-2010$ & & & \\
\hline Montana & $1965-1967$ & $1977-2010$ & & & \\
\hline Nebraska & $1965-1967$ & $1977-2010$ & & & \\
\hline Nevada & $1965-1967$ & $1977-2010$ & & & \\
\hline New Hampshire & $1965-1967$ & $1977-2010$ & & & \\
\hline New Jersey & \multicolumn{2}{|c|}{1965 - 2010} & & & \\
\hline
\end{tabular}




\begin{tabular}{lcc}
\hline \hline & June CPS & NLSY79 \\
\hline \hline \% of first marriages ending in separation: & 18.01 & 23.07 \\
Mean separation probability in a given year & $(0.38)$ & $(0.42)$ \\
\% having at most high school education: & 0.024 & 0.024 \\
& $(0.15)$ & $(0.15)$ \\
\% of women having a child during first marriage: & 41.03 & 37.25 \\
& $(0.49)$ & $(0.48)$ \\
\% of mothers having their first child before first marriage: & 65.46 & 76.39 \\
& $(0.47)$ & $(0.42)$ \\
Mean age at first marriage: & 16.91 & 9.01 \\
\% of marriages ending in years 1-2: & $(0.37)$ & $(0.28)$ \\
\% of marriages ending in years 3-4: & 24.72 & 25.06 \\
\% of marriages ending in years 5-6: & $(3.69)$ & $(3.60)$ \\
\% of marriages ending in years 7-8: & 2.18 & 2.15 \\
& $(0.146)$ & $(0.144)$ \\
\% of marriages ending in years 9-10: & 2.98 & 3.36 \\
& $(0.17)$ & $(0.18)$ \\
\% of marriages ending in years >=12: & 2.66 & 2.92 \\
& $(0.16)$ & $(0.16)$ \\
& 2.48 & 2.14 \\
& $(0.15)$ & $(0.14)$ \\
& 2.21 & 2.24 \\
& $(0.14)$ & $(0.14)$ \\
& 1.73 & 1.90 \\
& $(0.13)$ & $(0.13)$ \\
& 1.40 & 1.31 \\
& $(0.11)$ & $(0.11)$ \\
& 31573 & 1075 \\
& & \\
\hline
\end{tabular}

\section{Annual March CPS Data: Survey Years 1965 - 1995}

Standard deviation of male log wages

0.53

(0.047)

Mean male log-hourly real wage

Mean female log-hourly real wage

Mean male employment

Mean female employment

0.55

$(0.10)$

Sex ratio 
Appendix Table 3: Male wage inequality on marriage duration - NLSY79 (Robustness)

Dependent Variable $=1$, if separation takes place in a given year

(1)

(2)

(3)

(4)

(5)

Male wage inequality

$-0.052$

$(0.026)^{* *}$

$-0.073$

$-0.061$

Residual male wage inequality

$$
\begin{array}{cc}
-0.054 & -0.058 \\
(0.028)^{*} & (0.029) * * \\
& 0.016 \\
& (0.036)
\end{array}
$$

Residual female wage inequality

Male wage inequality 1 year prior to marriage

Male wage inequality 2 year prior to marriage

Male wage inequality 3 year prior to marriage

Male wage inequality 4 year prior to marriage

Male wage inequality 5 year prior to marriage

0.027

Wifes' s characteristics

Husband's characteristics \& income

Yes
Yes
Yes
Yes
Yes
No
7160

Yes
Yes
Yes
Yes
Yes
No
6922

Yes

Yes

Yes

Yes

Aggregate covariates

Period-specific dummies

Region \& year fixed effects

Region-year interactions

7160

6922

Yes

Yes

Yes

Yes Yes

Yes

Marriage-year observations

Coefficients are marginal effects of the explanatory variables from a logistic specification. See main text for information on the sample as well as the individual and state covariates. Standard errors (parentheses) are clustered by state-year. ${ }^{* * *},{ }^{* *}$,

* indicate significance at $1 \%, 5 \%$ and $10 \%$ respectively. 